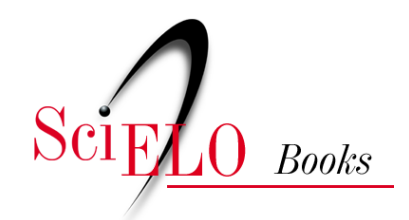

\title{
EDUFU
}

\section{Riqueza, pobreza e escravidão}

\author{
Luís Augusto Bustamante Lourenço
}

\section{SciELO Books / SciELO Livros / SciELO Libros}

LOURENÇO, L.A.B. Riqueza, pobreza e escravidão. In: A oeste das minas: escravos, índios e homens livres numa fronteira oitocentista Triângulo Mineiro (1750-1861) [online]. Uberlândia: EDUFU, 2005, pp. 225-280. ISBN 978-85-7078-516-9. https://doi.org/10.7476/9788570785169.0007.

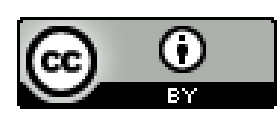

All the contents of this work, except where otherwise noted, is licensed under a Creative Commons Attribution 4.0 International license.

Todo o conteúdo deste trabalho, exceto quando houver ressalva, é publicado sob a licença Creative Commons Atribição 4.0.

Todo el contenido de esta obra, excepto donde se indique lo contrario, está bajo licencia de la licencia $\underline{\text { Creative Commons }}$ $\underline{\text { Reconocimento 4.0. }}$. 


\section{5 | Riqueza, pobreza e escravidão}

\section{A produção historiográfica sobre a Colônia e o Império}

Nos últimos 20 anos, uma nova geração de historiadores vem revisando conceitos antes estabelecidos sobre a História Colonial. Essa nova historiografia revê categorias como sistema colonial e sentido da colonização, questionando idéias como a de uma rígida polarização entre senhores e escravos, e flexibilizando o uso de conceitos marxianos como modo de produção, aplicados à sociedade colonial. Em parte, essa revisão decorre da proliferação de teses e dissertações produzidas por cursos de pós-graduação em todo o Brasil, com acesso a novas e inusitadas fontes.

Tais autores, como João Luís Fragoso, Manolo Garcia Florentino e José Roberto Góes, da UFRJ; ${ }^{1}$ Douglas Cole Libby, Júnia Ferreira Furtado, Eduardo França Paiva e Marco Antônio Silveira, da UFMG, ${ }^{2}$ vêm demonstrando, mediante o estudo de fontes como registros portuários e de tropas, testamentos e inventários post mortem, registros paroquiais e dados censitários, que a vida colonial era bem mais complexa do que se pode supor pela leitura de Gilberto Freyre, Caio Prado Júnior, Celso Furtado e Fernando Antônio Novais.

Uma das categorias que vem sendo revista é a de sistema colonial. Termo consagrado por Caio Prado Jr. (1986), e um dos conceitos centrais no importante livro de Fernando Novais (1986), deriva da concepção de que a sociedade colonial foi o resultado de uma grande empreitada do capital comercial, representado pelos comerciantes transatlânticos associados ao Estado Absolutista português. A economia da Colônia teria uma orientação exógena, voltada para a exportação de gêneros primários, cuja organização seria instada pelos interesses de uma burguesia comercial estabelecida no Reino, a única capaz de acumular no processo.

1 Ver, por exemplo, Florentino e Góes (1997); Fragoso (1998); e Fragoso e Florentino (2001).

2 Ver, por exemplo, Furtado (1999 e 2001); Paiva (2001); e Silveira (1997). 
Segundo essa vertente, a Colônia não contava com um mercado interno consistente. Sua pequena demanda seria suprida pela economia natural de subsistência das plantations, por áreas periféricas voltadas para o abastecimento interno, e pelas manufaturas trazidas pelos comerciantes da Metrópole. Não teria acesso, portanto, a nenhuma parte do excedente gerado nas atividades agroexportadoras ou na exploração aurífera. Disso resultaria uma polarização entre Colônia e Metrópole, uma contradição cujo esgarçamento se revelaria na crise do Antigo Sistema Colonial, do período pombalino (1750-1777) à chegada da Corte (1808), culminando na Independência em 1822.

$\mathrm{O}$ acesso a novas fontes primárias, nos últimos anos, vem revelando um quadro diferente daquele sugerido por esses estudos clássicos. Fragoso (1998) demonstrou que o mercado interno - na Colônia e nos primeiros tempos do Império - sustentou um processo de acumulação endógena realizado principalmente pelos comerciantes de grosso trato. Esses mercadores, estabelecidos no Rio de Janeiro, controlavam uma rede de abastecimento que, irradiando da capital da Colônia (e depois do Império), tentacularizava-se pelo Rio Grande do Sul, Paraná, São Paulo, Mato Grosso, Goiás e Minas Gerais. Estudando registros portuários, de tropas e inventários post mortem da capitania (depois província) do Rio de Janeiro entre 1808 e 1830, concluiu que a maior parte dos comerciantes de alimentos, dos negreiros e até mesmo dos exportadores do açúcar fluminense, estava estabelecida na praça do Rio de Janeiro. Furtado (1999), usando fontes semelhantes, relativas ao século XVIII, demonstrou a importância dos comerciantes portugueses radicados em Minas, ligados a redes de influência e favorecimentos que se irradiavam desde a Corte portuguesa.

Esses autores, em resumo, vêm recuperando a dimensão complexa da sociedade colonial. Não um mero reflexo de uma empresa mercantilista (embora também o fosse), mas dotada de um alto grau de autonomia, capaz de acumulações endógenas e de gerar um grande número de diferentes formas de produção. Uma economia que, além da dimensão agroexportadora, era marcada por uma profusa rede de fluxos internos, alimentados por setores mercantis de abastecimento, com um dinamismo próprio, e não exclusivamente subordinado às flutuações do mercado internacional.

Esses autores mostram que a Colônia - e o Império sob a Casa de Bragança - era parte integrante do mundo de seu tempo e, como tal, reproduzia muitas das características do império ibérico do Antigo Regime que a 
gerou. Silveira (1997) e Fragoso e Florentino (2001) mostraram que a ideologia que informava as elites coloniais estava muito longe do ethos capitalista. A vontade da distinção, a busca do prestígio por meio dos sinais exteriores de fidalguia, a repulsa aos ofícios mecânicos, a escravidão como valor, as formas de religiosidade, as hierarquias da sociedade de ordens, tudo isso distanciava o homem colonial da racionalidade do homo economicus capitalista.

Da mesma forma, as instituições jurídicas e políticas, com a não separação entre as estatais e as eclesiásticas, as formas jurídicas não-capitalistas de propriedade e posse fundiária, as formas políticas de poder patrimonial, com indistinção entre público e privado, tornavam o mundo colonial mais próximo de uma sociedade do Antigo Regime do que de uma sociedade capitalista.

Nesse sentido, Fragoso (1998) mostrou que sociedade colonial exibia aspectos de uma formação social pré-capitalista. O caráter monopolista do capital mercantil, a existência de mercados imperfeitos com baixa liquidez e escorados em formas de produção não-capitalistas, preços e oferta com oscilações freqüentes e imprevisíveis, forte concentração de riqueza, eram características tanto da economia colonial quanto das economias do Antigo Regime europeu.

Assim, a visão de uma Colônia funcionando como uma espécie de "negativo" da Metrópole, por ela moldada, dela dependente, mas dela diferente, porque capitalista avant la letre, vem sendo substituída por um novo paradigma que vê especificidades na experiência colonial (aliás, vê uma diversidade de experiências, formando um mosaico avesso a generalizações), mas dentro de um quadro geral, como parte do Império Português e das sociedades do Antigo Regime do ocidente.

O debate sobre as relações de produção que vigeram no período colonial e no Império também vem sendo marcado por uma mudança nos referenciais. Quanto a essa questão, duas vertentes firmaram-se na historiografia. $\mathrm{Na}$ primeira delas, Caio Prado Júnior (1986), Celso Furtado (1999) e Fernando Novais (1986) entenderam que o capitalismo comercial europeu gerou a Colônia e deu o sentido da colonização. O empreendimento colonial foi o que tornou possível a acumulação primitiva de capital pela burguesia da Europa. Desse modo, a economia e a sociedade coloniais seriam, desde sempre, marcadas pelas relações capitalistas de produção. E como o escravismo - um regime em que o trabalho não é realizado diretamente como mercadoria — pôde ser a base de uma sociedade capitalista? Novais resume a questão da forma seguinte: 
A produção colonial era, basicamente [...], produção para o mercado metropolitano, isto é, produção mercantil. Na economia de mercado, contudo, é o salariato o regime mais rentável; as formas de trabalho compulsório, por seu lado, vinculam-se a economias pré-mercantis [...]. Nesse sentido regime de trabalho prevalecente no mundo ultramarino do Antigo Regime se apresenta como um contra-senso (1986, p. 99).

E mais adiante, a partir de uma citação de Marx, tenta resolver o aparente paradoxo:

Marx, porém, implacável analista do mundo burguês, precisamente por ter levado sua análise para além de todas as mistificações da realidade, pôde constatar com nitidez que nas colônias eram desfavoráveis as condições de constituição do trabalho livre, sempre havendo a possibilidade de o produtor direto assalariado, apropriando-se de uma gleba de terra despovoada, transformar-se em produtor independente. Assim, enquanto a Europa moderna o desenvolvimento capitalista 'libertava' os produtores diretos da servidão medieval e integrava-os como assalariados na nova estrutura da produção que destarte camuflava a exploração do trabalho, as economias coloniais periféricas, montadas exatamente como alavancas do crescimento do capitalismo e integradas nas suas linhas de força, punham a nu essa mesma exploração na sua crueza mais negra [...] As colônias timbravam em revelar as entranhas da Europa (p. 101-102).

Em outras palavras, a presença de uma fronteira teria impedido a constituição de um mercado de trabalho livre; e o trabalho compulsório se teria imposto como forma possivel das relações de trabalho no contexto de uma economia colonial capitalista. Mas o escravismo, surgido nessas condições, não negaria o caráter capitalista das relações de produção.

Numa outra vertente, Ciro Flamarion Cardoso (1988), desde os anos 1980, vem criticando, de forma veemente, essa idéia de um capitalismo perene, existente desde o século XVI na sociedade brasileira. O fundamento teórico da idéia de Prado Jr. e Novais, segundo o autor, seria a definição de capitalismo a partir da esfera da circulação, quando, na verdade, é a esfera da produção o que dá a lógica e a dinâmica de um sistema. Disso derivaria outro erro, de implicações metodológicas mais graves, que é tentar ver uma racionalidade capitalista, de 
busca do lucro, entre os agentes da economia colonial.

$\mathrm{Na}$ mesma vertente, mas discordando em vários momentos de Cardoso, Gorender (1988) tenta, no seu O Escravismo Colonial, estabelecer as linhas gerais da dinâmica de reprodução do modo de produção escravista colonial. Nesse modo de produção, específico da experiência colonial das Américas, o trabalho escravo teria finalidade mercantil. Mas a circulação mercantil seria externa ao universo da produção, e sua dinâmica não determinaria as formas específicas de organização da economia escravista. Esta, em primeiro lugar, exigiria uma inversão inicial na compra do escravo pelo senhor, que Celso Furtado, Fernando Henrique Cardoso, Genovese e Fraginals identificaram ao capital fixo.

Segundo Gorender, as categorias trabalho e capital fixo seriam diferentes e inassimiláveis e, portanto, impossíveis de serem ambas imputadas à figura do escravo. O escravo poderia, no limite, funcionar como capital-dinheiro ou reserva de valor, mas não seria capital produtivo. O escravista, ao comprar do traficante o escravo, esterilizaria um fundo de riqueza em favor da compra de um poder sobre o trabalhador, poder de explorá-lo e acumular seu sobretrabalho. O escravo, nesse sentido, não venderia seu trabalho ao senhor em troca do alimento, como na relação de trabalho assalariado. A mercadoria em si não seria o trabalho, mas sim o escravo, ou o poder de coerção extra-econômica sobre o trabalhador escravizado.

Usando o conceito de Godelier de formação social, Fragoso (1998) vai mais além, definindo a sociedade colonial como um mosaico de formas de produção não capitalistas. Dentre elas, a forma de produção escrava, dominante, estaria presente na plantation do litoral. Mas esta, ao reproduzir-se, levaria ao surgimento de inúmeras outras, diferentes do escravismo de plantation, no próprio litoral ou em outras regiões, ligadas a ele por redes de abastecimento internas:

O escravismo colonial, em seu movimento de reprodução, teria criado no espaço colonial outras formas de produção não capitalistas: um escravismo ligado ao abastecimento interno, à unidade camponesa (com recurso ou não ao trabalho cativo), uma produção fundada no trabalho livre assalariado (estância). Desse modo, esses segmentos, criados e voltados para o abastecimento da agroexportação, seriam elementos subordinados em uma formação econômicosocial, cujo eixo seria aquele escravismo voltado para o abastecimento internacional (1998, p. 144). 
Outra questão que vem criando um novo consenso entre os historiadores, e que consideramos pertinente recuperar neste trabalho, é sobre o papel desempenhado pela população livre e pobre na sociedade escravista. Gilberto Freyre, em sua obra clássica Casa Grande e Senzala, não dedica nenhum de seus capítulos ao homem livre e pobre dos tempos coloniais. A justificativa aparece já no primeiro capítulo: embora reconheça a importância numérica da população livre, que Louis Couty calculava seis milhões, para uma população total de doze milhões em 1881,

Melhor alimentados eram na sociedade escravocrata os extremos: os brancos da casa grande e os negros das senzalas. Natural que dos escravos descendam os elementos mais fortes e sadios de nossa população. [...] E que da população média, livre mas miserável, provenham muito dos piores elementos, dos mais débeis e incapazes. [...] E quando toda essa quase inútil população de caboclos e brancarões, mais valiosa como material clínico do que como força econômica, se apresenta no estado de miséria física e de inércia improdutiva em que a surpreenderam Miguel Pereira e Belisário Pena, os que lamentam não sermos puros de raça nem o Brasil região de clima temperado o que logo descobrem naquela miséria e naquela inércia é o resultado de coitos para sempre danados, de brancos com pretas, de portugas com índias (1983, p. 34).

Gilberto Freyre teve o inegável mérito de livrar as ciências sociais brasileiras do racismo obsessivo que a contaminou até o início do século XX. Também inaugurou o que acabou se tornando moda nos anos 1980 e 1990, e que passou a ser chamado de "história das mentalidades". Mas a sua leitura dicotomizadora da sociedade escravista brasileira acabou influenciando toda uma geração de historiadores e sociólogos, mesmo críticos seus, que tendiam a ver na população livre uma classe de marginalizados anômicos, sem lugar na ordem escravocrata.

Prado Jr. (1986) demonstrou, antes de todos, a "escravidão como valor" nos tempos coloniais, isto é, uma instituição tida como universal e socialmente aceita, e na qual todos os grupos sociais tinham como ideal ter escravos. Mas, exatamente por isso, não haveria lugar para a população livre: 
Abre-se assim um vácuo imenso entre os extremos da escala social: os senhores e os escravos; a pequena minoria dos primeiros e a multidão dos últimos. Aqueles dois grupos são os dos bem classificados da hierarquia e na estrutura social da colônia. [...] Entre estas duas categorias nitidamente definidas e entrosadas na obra da colonização comprime-se o número, que vai se avultando com o tempo, dos desclassificados, dos inúteis e inadaptados; indivíduos de ocupações mais ou menos incertas e aleatórias ou sem ocupação alguma. Aquele contingente vultoso em que Couty mais tarde veria o "povo brasileiro", e que pela sua inutilidade daria como inexistente, resumindo a situação social do país com aquela sentença que ficara famosa: "Le Brésil n’a pas de peuple” (1986, p. 281).

Historiadores contemporâneos, como Laura de Mello e Souza, referiramse de forma semelhante à população colonial de forros, libertos e livres:

Muitos pontos comuns uniam pois os escravos [...], os forros [...], os homens livres pobres. Eram parte de um mesmo todo: a camada fluida e inconsistente que, apesar das formas esporádicas de solidariedade, nunca se enxergou como um grupo coeso. [...] [a visão de mundo da sociedade escravista colonial] foi a contrapartida da falta de consciência do homem livre pobre, a ideologia da vadiagem sendo um de seus principais pontos de apoio (1986, p. 219).

Sociólogos reproduziram a mesma concepção sobre a população livre do mundo escravocrata, aplicando-lhes o conceito durkheimiano de anomia social. Assim, o trabalho braçal, tido como inferior e associado à condição escrava, seria negado pelo livre ou forro, como uma forma de negar a própria condição escrava. Essa "ideologia da vadiagem" manteria a população liberta despreparada para o trabalho livre. Com a Abolição, teria sido selado seu destino de marginalidade, pobreza e violência. É o que lemos, por exemplo, em Florestan Fernandes:

Diante do negro e do mulato abrem-se duas escolhas irremediáveis, sem alternativas. Vedado o caminho da classificação econômica e social pela proletarização, restava-lhes aceitar a incorporação gradual à escória do operariado em crescimento ou abater-se penosamente, procurando no ócio dissimulado, na vagabundagem sistemática ou na criminalidade fortuita meios para salvar as aparências e a dignidade de 'homem livre' (1978, p. 28). 
Maria Sylvia de Carvalho Franco (1983), em estudo sobre os camponeses do Vale do Paraíba do Sul do final do século XIX, chega a conclusão semelhante, ao assinalar o "desperdício" de força de trabalho que caracterizava esses grupos, nascendo daí o "preguiçoso" caipira, cujos esforços limitavam-se a garantir a subsistência elementar, inexistindo entre eles uma regulamentação das relações de trabalho e uma moral disciplinadora do trabalho (p. 30-34). A mobilidade espacial dos caipiras, segundo a autora, impediria o surgimento de uma consciência grupal, tendo influência desagregadora; a cooperação vicinal, em formas como o mutirão, típicas do campesinato brasileiro, não se daria por condicionantes culturais, mas seria um ajustamento pessoal espontâneo, suscitado por situações imediatas, nas quais também facilmente a violência substituiria a cooperação.

Essa visão de uma população livre culturalmente amorfa e embrutecida, socialmente anômica, materialmente miserável, espacial e economicamente marginal foi criticada nos anos 80 por antropólogos como Gilberto Velho (1985). Historiadores, principalmente da UnICAMP nos anos 1980, como Sidney Chalhoub (1986), Robert Slenes (1999) e Sílvia Hunold Lara (1988), também apontaram a conotação ideológica do conceito de anomia social e os preconceitos de classe embutidos na visão dos pobres livres e libertos como "desclassificados".

Recentemente, novos trabalhos vêm dando ênfase à história social da família no período colonial, revelando a importância da população livre nesse período. Sheila Castro Faria (1998), analisando testamentos, inventários post mortem e documentos paroquiais da região de Campos dos Goitacases dos séculos XVIII e XIX, mostrou que família e parentesco são categorias centrais para compreender as populações pobres camponesas do período colonial, tanto nas relações de solidariedade quanto nas relações com a terra e nos processos migratórios.

Percebemos, em nossas fontes, a onipresença das famílias na organização social do Triângulo oitocentista, confirmando, em outra região, os estudos dessa autora. Apreendemos a importância quantitativa dos pequenos produtores livres, frente ao total da população. Assim, julgamos importante rever os conceitos de campesinato e trabalho familiar, antes de iniciarmos propriamente a exposição do resultado dos nossos estudos. 


\section{Chayanov revisitado: a economia política do campesinato}

As reflexões anteriormente expostas indicam que a historiografia parece caminhar para um consenso, no qual a sociedade colonial - e a sociedade do Império que a sucedeu - passa a ser vista como um mosaico de diferentes formas de produção, com suas respectivas lógicas produtivas e relações de trabalho. Estamos cada vez mais distantes do paradigma de uma sociedade colonial polarizada entre escravos e senhores, simplesmente.

Libby (1988), analisando os Mapas de População, concluiu que a grande propriedade escrava em Minas Gerais era a exceşão e não a regra. A maioria dos fogos não contava com um escravo sequer (66,7\% do total), ao mesmo tempo em que um terço da população livre era proprietária de escravos. O maior grupo de proprietários de cativos era o dos que possuíam entre 3 e 5 escravos (28\% do total de proprietários). O autor chamou esse padrão de distribuição da propriedade cativa de "posse democrática" de escravos. Marcílio (2000) já havia detectado, antes, uma estrutura de posse mancípia semelhante, em seus estudos de demografia histórica da capitania de São Paulo do período setecentista. Castro Faria (1998) chegou à mesma conclusão em seu trabalho sobre as estruturas de riqueza e familiares de Campos dos Goitacases no século XVIII.

Fragoso (1998) fez uma revisão de vários trabalhos relativos à economia mineira oitocentista, e concluiu que, naquela província, particularmente nas regiões Sul, Oeste, Alto Paranaíba e Triângulo Mineiro:

Os números não apenas sugerem que o senhor de escravos padrão de Minas Gerais era o pequeno proprietário, mas apontam também para o fato de que a base da economia mercantil mineira voltada para o mercado interno dificilmente poderia ser classificada apenas como escravista. Em unidades econômicas com menos de cinco escravos, mesmo considerando que todos estariam em atividades produtivas, não seria de estranhar que, ao lado do cativo, surgisse o trabalho familiar dos detentores da unidade. E, avançando um pouco mais, mesmo reconhecendo que não temos base empírica para isso [grifo do autor], aquele padrão nos insinua que estamos diante de uma situação próxima à de unidades camponesas que complementam o trabalho familiar com o de outras categorias sociais, no caso o escravo (1998, p. 131). 
Nosso levantamento, fundamentado em inventários post mortem do termo da freguesia (depois vila) de Uberaba, na primeira metade do século XIX, cujo termo abrangia praticamente duas terças partes do que hoje se conhece por Triângulo Mineiro, parece confirmar o que Fragoso intuiu. Para caracterizar um conjunto de pequenas unidades produtivas como camponesas, com ou sem escravos, recorremos à metodologia desenvolvida por Alexander Chayanov.

Esse economista russo da primeira metade do século XX vem sendo relido por economistas contemporâneos, como Ricardo Abramovay (1998), por exemplo. Esse autor destacou que a insuficiência do pensamento marxiano, relativo ao conceito de campesinato, tal como aparece n'O Capital, não é devida a limitações da construção teórica marxiana em si, mas sim porque tal conceito não se encaixa em nenhuma de suas categorias. Todas as definições de campesinato dos autores clássicos marxistas foram feitas de forma negativa: alguém que não vende sua força de trabalho e não vive do trabalho alheio. O camponês, numa sociedade capitalista, seria o que não faz parte do proletariado e nem o explora.

Chayanov, partindo de uma perspectiva diferente, afirmou que a economia camponesa pode ser objeto de um conhecimento racional: é no interior do organismo camponês que se devem procurar as razões da existência dos camponeses. As categorias usadas para a economia capitalista não valem para a economia camponesa, ou, em outras palavras, a racionalidade da economia camponesa é incompreensível dentro dos parâmetros contábeis da economia capitalista (ABRAMOvay, 1998).

O economista russo começou por caracterizar o campesinato como um sistema econômico não-capitalista, por inexistir nas unidades familiares de produção o assalariamento e, portanto, a mais-valia e o lucro. A formação de preços, nesse sentido, obedece a uma lógica diferente da capitalista, pois a produção interessa exclusivamente em seu valor de uso, mesmo quando é realizada como valor de troca no mercado (CHAYANOv, 1986).

E qual seria a lógica da produção camponesa? O que o autor chamou de equilíbrio trabalho-consumo, isto é, o volume de trabalho da economia camponesa depende da medida em que o resultado desse trabalho satisfaz as demandas de consumo familiares:

A medida da auto-exploração depende no mais alto grau do quanto o trabalhador é carregado pelas demandas dos consumidores. O volume da atividade familiar 
depende inteiramente do número de consumidores e não do número de trabalhadores (CHAYANOv, 1986, p. 78).

Os trabalhadores da unidade familiar aumentariam seu esforço de trabalho, até o ponto em que percebessem que qualquer aumento marginal deste não levaria a aumentos significativos no grau de satisfação do consumo. Nesse momento, o aumento do esforço de trabalho seria interrompido e a unidade chegaria num ponto de equilíbrio.

Veremos, a seguir, se o modelo chayanoviano de unidade familiar camponesa pode ser usado para entender a sociedade de criadores e roceiros do Triângulo Mineiro, na primeira metade do século XIX. Antes, usando como fonte os inventários post mortem da freguesia — depois vila — de Uberaba de 1822 a 1861, reconstituiremos o universo do trabalho no qual viviam as pessoas daquele tempo e região.

\section{A divisão social do trabalho no Triângulo Mineiro oitocentista}

Um aspecto que chama a atenção na leitura dos inventários post mortem da vila de Uberaba é o baixo nível de divisão social do trabalho entre as unidades rurais, de diferentes tamanhos. Em fazendas grandes ou pequenas, sítios ou chácaras, encontramos a mesma gama de equipamentos técnicos, diferindo apenas em escala um do outro. Por isso, seria forçada e extemporânea uma tentativa de classificar em setores primário, secundário e terciário, as atividades de uma economia colonial e pré-capitalista. Seriam termos mais apropriados a ordenamentos capitalistas com um alto grau de especialização do trabalho.

Assim, tanto em grandes quanto em pequenas unidades, encontramos o mesmo universo produtivo, em diferentes dimensões. O capitão Antônio José de Araújo ${ }^{3}$ possuía, em 1838, um formidável patrimônio constituído pela Fazenda São Francisco, em Dores do Campo Formoso, de 14.400 alqueires no valor de 40:040\$000. Dispunha de um plantel formado por 21 escravos, a maioria homens em idade produtiva, somando 9:700\$000 em patrimônio mancípio. Esse fazendeiro podia ser considerado um grande criador para os

3 APU, Inventário do Cap. Antônio José de Araújo (20/03/1838), caixa 459. 
padrões da época, pois contava com um rebanho de 277 vacas de criar, 114 garrotes para engorda e 30 bois carreiros, que somava 3:845\$000. Terras, escravos e gado perfaziam 76\% do patrimônio de Antônio José.

O que chamaríamos hoje de "capital fixo" desse fazendeiro era constituído por um sítio com moinho, paiol, monjolo coberto de capim, currais de aroeira, senzalas e rego d'água, que valiam um conto de réis; uma engenhoca de trezentos mil réis; e ferramentas (quatro carros de boi e um carretão, cinco machados, doze enxadas, oito foices, uma alavanca e uma cavadeira), que somavam $157 \$ 000$. O equipamento técnico do rico fazendeiro equivalia a apenas $2 \%$ do seu patrimônio total!

Numa unidade de porte médio, como a fazenda de João Alves de Resende, ${ }^{4}$ em São Pedro do Uberabinha, ${ }^{5}$ em 1850, encontramos os mesmos traços das unidades maiores: um mínimo de ferramentas e benfeitorias, e uma gama de atividades que iam do artesanato doméstico à pecuária extensiva, passando pelo cultivo e beneficiamento de alimentos. Esse sitiante possuía dois casais de escravos, pais de duas crianças. Com eles, sua esposa Lina e mais os filhos adolescentes Manuel e Antônio cultivavam umas roças às margens do Rio Uberabinha. No chapadão, que se estendia daí até o rio das Velhas, criava 34 cabeças de gado, contando com quatro cavalos e um burro. Lina e as escravas Josefa e Delfina usavam um descaroçador, três rodas de fiar e um tear para a produção doméstica de panos de algodão. João, seus filhos e os escravos Custódio e Francisco dispunham também de enxó e formões, para a carpintaria doméstica da curralama, dos carros, dos esteios das casas e demais benfeitorias de seu sítio. Seu sítio dispunha de um moinho, um paiol e um monjolo. $\mathrm{Na}$ verdade, do ponto de vista técnico, trata-se do mesmo universo produtivo da Fazenda São Francisco, do afortunado capitão Antônio, a algumas léguas dali, diferindo daquela apenas em escala.

O exame de uma pequena unidade revela traços constitutivos semelhantes. João Inácio de Sá ${ }^{6}$ e sua esposa, em 1829, criavam a filha Claudina, de dois anos, numa casa coberta de capim, com paiol e monjolo, em sua pequena propriedade (uns 50 alqueires aproximadamente ${ }^{\top}$ ) na Fazenda Areão. Com o

\footnotetext{
APU, inventário de João Alves de Resende (05/02/1850), maço N16, caixa 470.

Hoje Uberlândia.

APU, Inventário de João Inácio de Sá (02/04/1829), maço N46, caixa 451.

Em muitos inventários post mortem, como neste caso, a área das propriedades não era espe-
} 
auxílio de seu escravo Antônio, e contando com dois cavalos, João criava o seu pequeno rebanho de 15 reses, dos quais seis eram vacas de leite e seis bois de carro, mais 25 porcos. Sua esposa Maria e uma escrava homônima de 14 anos fiavam e teciam, usando duas rodas e um tear. As ferramentas que João e Antônio utilizavam, em seu trabalho diário, resumiam-se a quatro foices, cinco enxadas, quatro machados e um carro. Novamente, o que se verifica é o mesmo das grandes e médias unidades: diversidade de atividades produtivas, baixo nível de investimento em "capital constante", técnicas produtivas elementares, com alto nível de dependência da natureza.

Mesmo quando detectamos pessoas especializadas em algum ofício — alfaiates, ferreiros, carpinteiros, cirurgiões-barbeiros —, o exame de seus inventários revela que também possuíam bens rurais, e suas profissões eram apenas um complemento ao núcleo produtivo doméstico, formado basicamente por atividades agropastoris.

Por exemplo, o carpinteiro Manuel Antônio da Silveira, ${ }^{8}$ em 1838, contava apenas com os filhos moços João, Jerônimo, José e Deodoro para ajudá-lo no ofício, já que não dispunha de escravos homens. No entanto, provavelmente suas carpintarias apenas complementavam a renda da família, pois era dono de uma pequena extensão de terras na Fazenda do Buracão, em Dores do Campo Formoso, onde cultivava e criava um pequeno rebanho de dezoito cabeças de gado. Noutro exemplo, sabemos que Miguel Martins Morgado9 exercia o ofício de cirurgião barbeiro, em 1828, pois em seu inventário lemos que possuía navalhas de sangrar, ventosas, e quatro livros de medicina Buchan. No entanto, só devia oferecer seus préstimos de esculápio esporadicamente, quando solicitados por algum doente na freguesia de Uberaba, já que cultivava e criava bois em sua fazenda, auxiliado pelos filhos Miguel e João, pelo pequeno José, de 10 anos, e pelos africanos João e Vicente.

Em parte, esse baixo nível de divisão social do trabalho devia-se à própria condição de fronteira da região em estudo. A baixa densidade

cificada, mas apenas o seu valor. Porém, tomando por base a média dos preços da terra nos inventários post mortem, que especificavam a área, calculamos o valor aproximado da terra em diferentes épocas, que mostraremos numa tabela mais adiante. A partir dessa tabela, calculamos esta área baseados num preço médio do alqueire — considerando uma proporção de terras de cultura e de campos de aproximadamente 1:2 — de $3 \$ 000$.

8 APU, inventário de Lauriana Teresa dos Santos (14/08/1838), maço N4.

9 APU, inventário de Miguel Martins Morgado (07/07/1828), maço N35, caixa 459. 
demográfica e as grandes distâncias em relação aos centros mais dinâmicos faziam com que as unidades agropastoris - fossem elas pequenos sítios ou grandes fazendas - buscassem a auto-suficiência. Somente quando se aumentasse a densidade demográfica, crescessem os arraiais e vilas, e se estabelecessem fluxos mais intensos com as regiões mais povoadas, é que se abriria a possibilidade de uma maior realização mercantil dos excedentes. Só assim os produtores passariam a ver a especialização como vantajosa, pois poderiam aumentar os ganhos com a economia de escala e, assim, a divisão social do trabalho seria um pouco mais estimulada. Não é outro o diagnóstico de Saint Hilaire, referindo-se aos agricultores e criadores que conhecera na capitania de Goiás, em 1819:

Mas para que uma região seja verdadeiramente rica não basta que seja fértil. É preciso também que tenha facilidade para realizar trocas de mercadorias, a fim de obter as coisas que não produz. A enorme distância que separa Goiás das grandes cidades e dos portos do Mar não permite aos colonos exportarem produtos que, sendo muito volumosos, têm contudo pouco valor. Além do mais, o milho, a mandioca, o arroz, o feijão e o café não encontram mercado fácil na própria região, devido ao fato de serem cultivados em toda ela. Sendo de um modo geral agricultores, os goianos plantam para o próprio consumo [...] (1975 b, p. 181).

$\mathrm{Na}$ Serra da Canastra, nas proximidades do Desemboque, o cronista registrou que um roceiro "com exceção do sal suas terras produzia com abundância tudo o que ele tinha necessidade" (1975 b, p. 102).

É necessário esclarecer, contudo, que tais aspectos da economia agropastoril do Extremo Oeste de Minas, certamente intensificados pela condição de fronteira em que então se encontrava, não estavam fadados a desaparecer assim que a região se inserisse num sistema de trocas mais dinâmico. Nossa hipótese é a de que tais aspectos, detectados na região em estudo, eram estruturais à economia colonial, já que se tratava de uma formação social onde formas de produção não-capitalistas — dentre elas, as unidades agropastoris escravistas, camponesas e camponesas com escravos reproduziam-se, conectadas entre si por uma extensa rede mercantil. Veremos, nesse contexto, como essa sociedade acumulava riquezas, e que tipo de bens poderiam receber esse nome. 


\section{Formas de riqueza}

No mundo das unidades de produção agropastoris sertanejas, a acumulação de excedentes não se fazia principalmente na forma de capital, se dermos a esta palavra o sentido marxiano, isto é, algo capaz de se reproduzir seguindo a fórmula geral D - M - D'. A propriedade fundiária, por exemplo, conforme o próprio autor d'O Capital,

pressupõe que certas pessoas têm o monopólio de dispor de determinadas porções do globo terrestre como esferas exclusivas de sua vontade privada, com exclusão de todas as outras. [...] O poder jurídico dessas pessoas de usar e abusar do globo terrestre em nada contribui para a valorização da terra. A utilização dessas porções depende inteiramente de condições econômicas que são independentes da vontade desses proprietários. A própria concepção jurídica quer dizer apenas que o proprietário fundiário pode proceder com o solo assim como com as mercadorias o respectivo dono (1983, v. 3, p. 124).

Mais adiante continua:

O nível de renda fundiária (e com ele o valor da terra) desenvolve-se ao longo do desenvolvimento social como resultado do trabalho social global. Por um lado, cresce com isso o mercado e a demanda de produtos da terra; por outro, imediatamente cresce a própria demanda de terras, como condição para a produção competitiva para todos os ramos possíveis da produção, mesmo os não agrícolas (p. 139).

Dito da forma que nos interessa aqui, o preço da terra se forma com base na renda fundiária que, por sua vez, depende da competição por terra pelos agentes produtivos. É no mercado, portanto, que o valor da propriedade fundiária se forma, e não como valor-trabalho, já que a propriedade fundiária não é resultado de acúmulo de sobretrabalho, mas do estatuto jurídico que garante a propriedade ao proprietário. Portanto, terra pode se tornar mercadoria que se realiza no mercado como valor-dinheiro. É riqueza, mas não capital em si.

Do mesmo modo, a outra forma de riqueza dos proprietários da região e do período em estudo, a posse de cativos, já vimos não poder ser identificada 
ao capital. Um outro trecho de Marx contribui ainda mais para esclarecer a natureza do trabalho escravo:

A força de trabalho como mercadoria só pode aparecer no mercado à medida e porque ela é oferecida à venda ou é vendida pelo seu próprio possuidor, pela pessoa da qual ela é a força de trabalho. Para que seu possuidor venda-a como mercadoria, ele deve poder dispor dela, ser, portanto, livre proprietário de sua capacidade de trabalho, de sua pessoa. Ele e o possuidor de dinheiro se encontram no mercado e entram em relação um com o outro como possuidores de mercadorias iguais por origem, só se diferenciando por um ser comprador e o outro, vendedor, sendo portanto ambos juridicamente iguais. [...] As condições bistóricas [de existência do capital] de modo algum estão presentes na circulação mercantil e monetária. Ele só surge onde o possuidor de meios de produção e de subsistência encontra o trabalhador livre como vendedor de sua força de trabalho no mercado [grifos nossos] (1983, v. 1, p. 139-141).

A condição para que o capital se remunere é a existência de trabalhadores livres e vendedores de sua força de trabalho, juridicamente iguais, unidos por uma relação que se estabelece no interior da dinâmica econômica. Se não é trabalhador livre, sua força de trabalho não é "capital variável”, pois sua força de trabalho não é negociada livremente no mercado. Tampouco é "capital constante", pois não é uma mercadoria produzida por outrem, que, uma vez adquirida, vai agregando valor a outras mercadorias à custa de seu próprio desgaste.

$\mathrm{O}$ trabalho escravo segue uma lógica diferente desta. Fundamenta-se na existência de um estatuto jurídico que diferencia os homens em livres e escravos, estes sendo propriedade dos primeiros, que podem assim aplicar sobre eles uma coerção extra-econômica e se apropriar de todo o excedente do trabalho realizado. As relações de produção no escravismo se estabelecem antes no plano político, pela legitimação do poder de um homem sobre outro, e depois no plano econômico, pelas relações de trabalho.

O escravo é capital apenas numa situação: nas mãos do traficante, na forma de mercadoria e, deste modo, capital circulante, que ao realizá-lo na forma dinheiro, obtém lucro de monopólio. Assim, embora o escravo possa assumir a condição de capital na circulação mercantil, não pode ser identificado ao capital produtivo quando submetido à exploração. 
Dito isto, resta examinar, por meio de nossa amostragem, as principais formas de acumulação de riqueza entre fazendeiros, sitiantes e agregados no Triângulo Mineiro oitocentista. Agrupamos os inventários por níveis de riqueza, baseando-nos nos montes-mores convertidos em libras esterlinas, uma moeda mais estável, ${ }^{10} \mathrm{de}$ forma a podermos comparar montantes de épocas diferentes.

Calculamos a média dos percentuais relativos às principais formas de riqueza dos montantes de cada nível, no período de 1822 a 1850. Excluímos os inventários posteriores a 1850 de nossa amostra, por duas razões. A primeira é que, conforme mostra o gráfico 1 , o preço do escravo no termo da vila de Uberaba aumentou muito em valores reais, de $1851 \mathrm{em}$ diante, por causa da extinção do tráfico transatlântico, fazendo com que, dessa época em diante, maior percentual de riqueza fosse imobilizado na forma escravo, impossibilitando comparações com a época anterior. De forma semelhante, conforme foi visto no gráfico 1 do capítulo 3, com a Lei de Terras de 1850, e com o crescente aumento da densidade de ocupação, o preço da terra, dessa data em diante, aumentou em valores reais no Triângulo Mineiro, principalmente da terra de cultura.

Feitas essas ressalvas, podemos apreciar as formas de riqueza no Triângulo Mineiro de 1822 a 1850, distribuídas por nível de riqueza, no gráfico 2. Pode-se perceber, em primeiro lugar, que escravos e terra constituíam a principal forma de riqueza para todas as faixas, inclusive pequenos sitiantes, respondendo em todas elas por pelo menos $70 \%$ do total dos cabedais. Portanto, o excedente era acumulado sob formas não-capitalistas de riqueza, independente da posição na hierarquia social.

Em segundo lugar, percebe-se que, entre as grandes fortunas (maiores que 5.000 libras), a propriedade de terras ultrapassava os escravos como principal forma de riqueza. Isto não se dava porque a terra subia de valor nas mãos dos grandes. O preço unitário do alqueire era muito baixo, na verdade. No inventário de Maria Rodrigues de Jesus, ${ }^{11}$ por exemplo, um alqueire de terra de cultura no Veríssimo foi avaliado em $4 \$ 000$, algo como o preço de uma foice de ferro... O que ocorria era uma formidável concentração fundiária, que fazia dos grandes fazendeiros verdadeiros landlords. O tenente Joaquim Silva Oliveira, morto em

\footnotetext{
10 Usamos a tabela de conversão que se encontra em Mattoso (1990).

11 APU, Inventário de Maria Rodrigues de Jesus (04/04/1829), maço N48, caixa 459.
} 


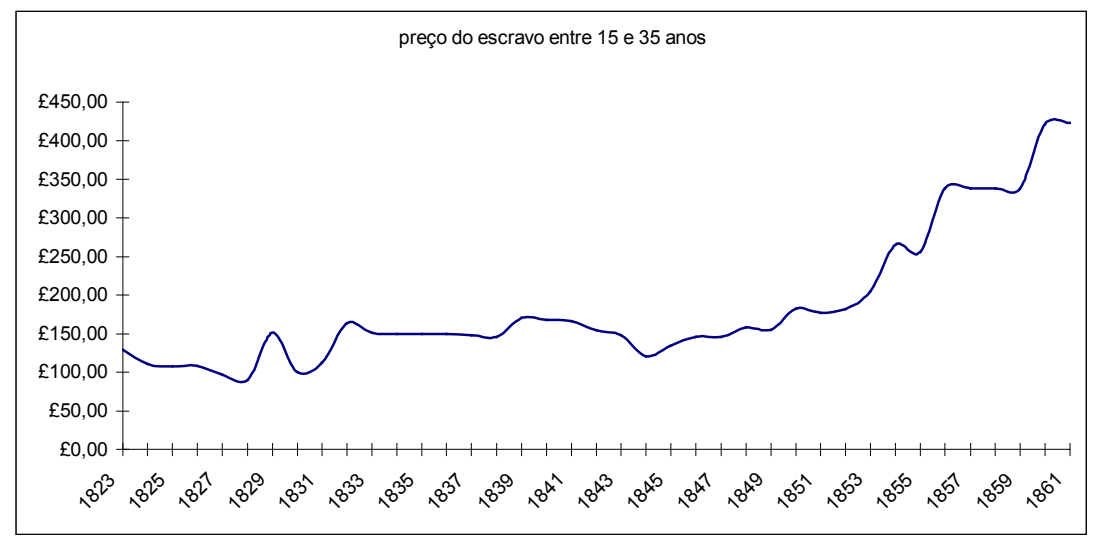

Gráfico 1: preço do escravo entre 15 e 36 anos, do sexo masculino, no termo de Uberaba, entre 1822 e 1861 (em libras esterlinas).

Fonte: APU, inventários post mortem (1822-1861).

1839, membro da parentela fundadora de Uberaba e dono de um plantel com 42 escravos, era dono de nada menos que 12.336 alqueires em três fazendas, somando 67 contos de réis em patrimônio fundiário! ${ }^{12}$

Apesar de as formas de riqueza serem semelhantes em qualquer nível de riqueza, esta era uma sociedade com uma hierarquia econômico-social profundamente diferenciada. Podemos estimar quantitativamente a distribuição da riqueza pelo cálculo do coeficiente de Gini, usando como fonte os cabedais inventariados, convertidos em libras esterlinas (gráfico 3 ).

Ressalvamos que a amostra de patrimônios inventariados não é representativa de toda a sociedade, ficando de fora os muito pobres, que não tinham nenhum bem a legar em herança, e os escravos, a quem era negado o direito à propriedade de si mesmo. Assim, a real concentração de riqueza era certamente muito maior do que a que calculamos. Mas podemos comparar nossos números com os obtidos por outros autores, relativos a outras regiões do Brasil da mesma época.

O valor de 0,67 é próximo do encontrado por Alice P. Canabrava para localidades da capitania de São Paulo do século XVIII, como Mogi-Guaçu em 1765 (0,66) ou Juqueri em 1767 (0,67) (LunA \& CostA, 1982), o que seria

12 APU, Inventário de Joaquim da Silva Oliveira, 06/03/1839, maço N\&, caixa 461. 


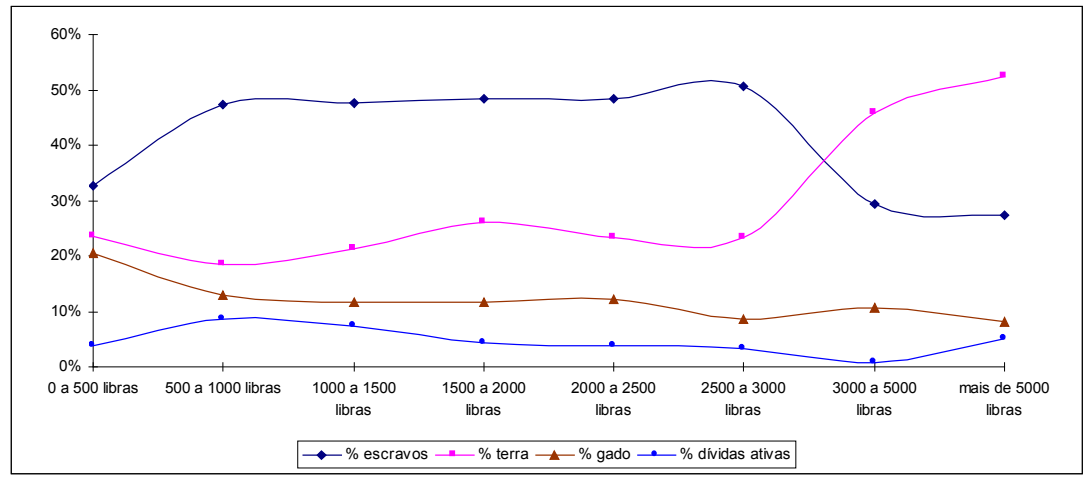

Gráfico 2: principais formas de riqueza no termo de Uberaba, entre 1822 e 1850, por faixa de riqueza (em libras esterlinas).

Fonte: APU, inventários post mortem (1822-1861).

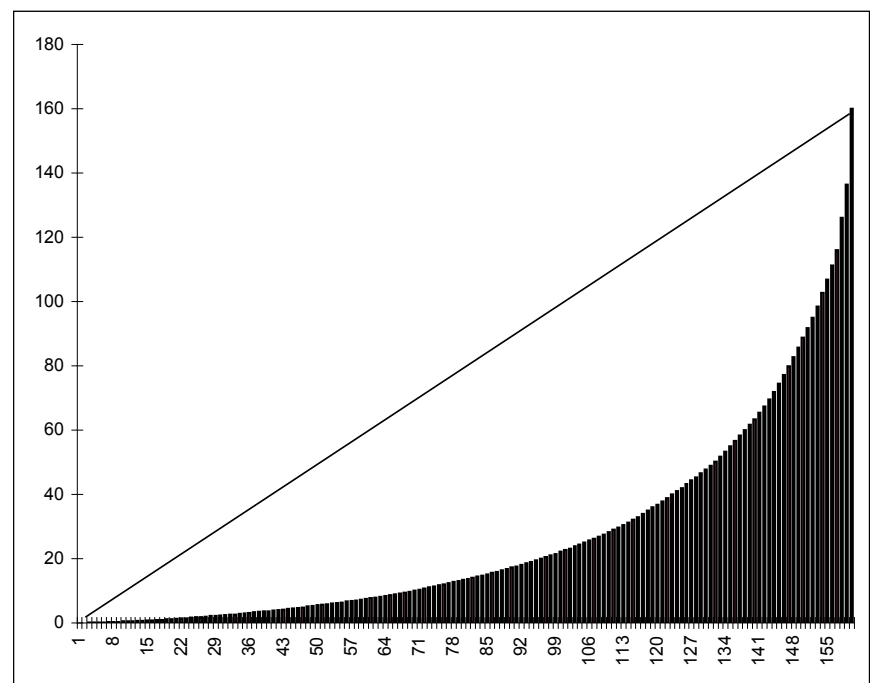

Gráfico 3: distribuição da riqueza nos inventários post mortem do termo de Uberaba de 1822 a 1861 (curva de Lorenz para cálculo do coeficiente de Gini).

Fonte: APU, inventários post mortem (1822-1861). 


\begin{tabular}{ll}
\hline SOMA & 4207,51782 \\
\hline ÁREA DO TRIÂNGULO & 12800 \\
\hline ÁREA DE LORENTZ & 8592,48218 \\
\hline GINI & 0,6713 \\
\hline
\end{tabular}

Gráfico 3: distribuição da riqueza nos inventários post mortem do termo de Uberaba de 1822 a 1861 (curva de Lorenz para cálculo do coeficiente de Gini) Fonte: APU, inventários post mortem (1822-1861).

de se esperar, pois apresentavam estruturas sócio-econômicas semelhantes às da região em estudo.

Luna e Costa (1982) compararam os dados que obtiveram a partir da distribuição da posse de escravos na região metalúrgica de Minas, entre 1718 e 1822, com os resultados de Canabrava. O coeficiente de Gini, calculado pelos autores, variou de 0,403 (Pitangui) a 0,573 (Serro do Frio), o que serviu para que concluíssem que, em Minas, ao tempo da extração do ouro, havia uma distribuição de riqueza mais homogênea do que em São Paulo. Trata-se, contudo, de dados de natureza diferente: não se pode comparar distribuição de posse de cativos com distribuição de riqueza total, pois havia um grande contingente de não-proprietários de escravos inventariados. Calculamos o coeficiente de Gini relativo à posse mancípia em nossa amostra e chegamos ao número de 0,57 , próximo ao obtido por aqueles autores. Talvez, se fossem feitos estudos relativos à distribuição da riqueza total na região aurífera-metalúrgica dos séculos XVIII e XIX, também ali se chegaria a uma estrutura próxima à de São Paulo ou do Triângulo Mineiro.

Escravos e terra não eram a única forma de riqueza, contudo. O gráfico 2 mostra que gado e dívidas ativas representavam aproximadamente um quinto do total da riqueza em todas as faixas. Por meio das dívidas ativas, podemos ter uma idéia do capital usurário que financiava as atividades produtivas daquela economia. O gráfico 4 mostra o valor médio do patrimônio mobilizado em dívidas, dividido por faixa de fortuna. Até a faixa de fortuna de 5.000 libras, a média de dívidas a receber flutua abaixo de $400 \$ 000$, para saltar acima de 1:800\$000 na faixa das grandes fortunas (maiores que 5.000 libras). Isso mostra, inequivocamente, que nessa faixa de fortuna os inventariados mobilizavam parte de sua riqueza como capital usurário. 
De fato, o já citado tenente Joaquim Silva Oliveira era credor de 25 pessoas, num total de 6:603\$400 mobilizados em crédito. A dívida de Antônio Mendes, por exemplo, foi citada como "um crédito de seiscentos e cinqüenta e quatro mil réis de principal mais prêmio de duzentos e vinte e cinco mil e noventa e cinco réis", o que significa juros de 34\%, provavelmente anuais. Dentre os devedores do rico uberabense, encontravam-se outros fazendeiros de porte, a deduzir pelos postos da Guarda Nacional que alguns ostentavam (o que era comum entre homens de fortuna), como o guarda-mor Antônio José Teixeira, o capitão Honório de Araújo ou o alferes Melquíades Coelho de Siqueira, e até mesmo religiosos, como o padre Lourenço Pereira da Silva e o vigário Antônio José da Silva. ${ }^{13}$

Os viajantes do período joanino forneceram alguns elementos para se entender como funcionava o sistema de crédito e endividamento na região, entre 1816 e 1819. Em Araxá, Eschwege referiu-se aos fazendeiros usurários:

Os fazendeiros [...] vendem qualquer coisa à vista. Por outro lado, são capazes de abrir crédito a prazos dilatados e juros de 100\%. Vencido o prazo da dívida, é comum a penhora dos bens do devedor [...] resultando disso inúmeros processos judiciais em que ambas as partes se comprometem. Não raramente, o caso acaba em assassinato (1996, p. 109).

Saint Hilaire, também em Araxá três anos depois, referiu-se à cadeia de endividamentos a que estavam presos os pequenos sitiantes:

O mais provável é que estes homens, cujas propriedades são tão novas, não tenham disposto de capital no princípio, comprando a crédito e talvez pagando com elevado juro seus escravos e tudo o mais que compõe os seus bens. Conseqüentemente são pobres, já que não são propriamente donos de tudo o que lhes parece pertencer (1975 b, p. 126).

Esses fazendeiros que ofereciam crédito, por sua vez, eram devedores de capitalistas e instituições de fora da região. O capitão José de Miranda

13 APU, inventário de Joaquim da Silva Oliveira (06/03/1839), maço N7, caixa 461. 


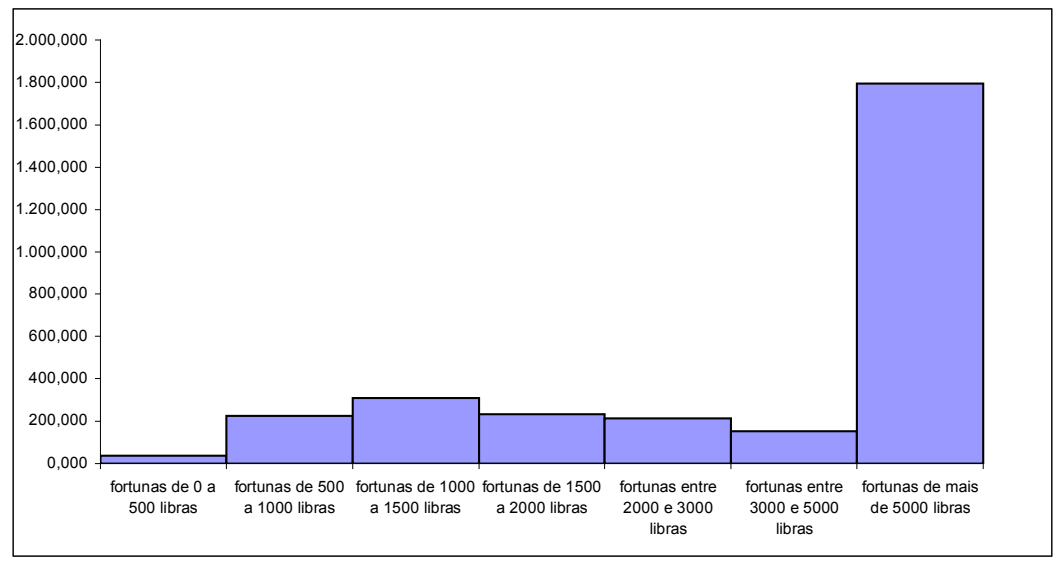

Gráfico 4: valor médio do patrimônio formado por dívidas ativas, por faixa de fortuna, no termo de Uberaba, entre 1822 e 1861 (em réis)

Fonte: APU, inventários post mortem (1822-1861).

Ramalho, ${ }^{14}$ de Carmo dos Dois Morrinhos, ${ }^{15}$ senhor do engenho de Bebedor Grande com 33 escravos, era credor de dívidas que totalizavam 1:372\$000. Ao mesmo tempo, devia 4:964\$738 a Antônio José Lopes de Araújo, da Corte do Rio de Janeiro, e mais 322\$027 à Santa Casa de Misericórdia do Rio Janeiro. Havia, na verdade, uma cadeia de endividamentos que se irradiava desde a capital do Império, e que, transitando pelas rotas comerciais para o sertão, ali chegando, disseminava-se pela hierarquia econômico-social a partir dos grandes fazendeiros.

O quadro que estamos delineando é muito próximo daquele traçado por Fragoso (1998) relativo ao Rio de Janeiro e Vale do Pará́ba da mesma época, respeitadas as proporções entre uma região central e outra periférica do Império. Também ali, estudando séries de inventários post mortem de 1797 e 1860, esse autor encontrou uma frágil divisão social do trabalho; mercados imperfeitos devidos à pouca expressão do trabalho assalariado e ao predomínio de formas não capitalistas de produção; brutal desigualdade na distribuição de riqueza; forte concentração do capital usurário no topo da hierarquia social e

\footnotetext{
14 APU, inventário de José de Miranda Ramalho (03/08/1844), maço 2.

15 Hoje Prata.
} 
uma cadeia de endividamentos se irradiando daí aos outros níveis.

Quanto à distribuição da riqueza, elaboramos a tabela 1, comparando nossos dados aos do Rio de Janeiro. Vê-se em ambos uma estrutura fortemente concentrada, contudo mais pronunciadamente na Corte do que no Triângulo Mineiro. Isso se explica pela presença, na capital do Império, dos comerciantes de grosso trato, detentores dos maiores cabedais em todo o país na época. De fato, das maiores fortunas cariocas, cinco eram fortunas mercantis ou rentistas e apenas três eram fortunas rurais. Das fortunas rurais do Rio de Janeiro, a maioria situava-se entre 5.000 e 20.000 libras (FrAgoso, 1998), faixa que no Triângulo Mineiro correspondia a $82 \%$ do total das fortunas maiores de 5.000 libras. Isto é, embora o Triângulo não contasse com os admiráveis patrimônios de mercadores do porte de um Brás Carneiro Leão, do Rio de Janeiro, de inacreditáveis um mil e quinhentos contos de réis, ultrapassando inclusive os fundos do Banco do Brasil em 1809 (Fragoso, 1998), as suas grandes fortunas rurais comparavam-se àquelas da Capital, na primeira metade do século XIX.

Por outro lado, a região em estudo não contava, nesse período, com grandes fortunas mercantis. Localizamos os inventários de três comerciantes em nossa amostra: dois ambulantes, com fortunas de $1: 983 \$ 472$ e de $2: 478 \$ 4460$, e um outro estabelecido no arraial de Uberaba, com venda aberta e botica, que possuía um patrimônio de 5:466\$336. No próximo capítulo, estaremos estudando a atuação desses mercadores na região, mas o que nos interessa neste momento é a posição que ocupavam na hierarquia econômica e social. Tratavase, na classificação estabelecida por Júnia Ferreira Furtado (1999), de negociantes a retalho, isto é, varejistas fixos ou volantes que comercializavam fazendas secas e boticas. A região não dispunha, pelo menos na primeira metade do século XIX, de comerciantes de grosso trato. Os vendeiros e mascates dos sertões mineiros recebiam gêneros de atacadistas de São João Del Rei e Barbacena, que operavam como intermediários entre os grandes fornecedores do Rio de Janeiro e o mercado sertanejo (FURTADO, 1999).

Basta analisar suas dívidas ativas para constatarmos que, diferentemente dos homens de negócio cariocas, não eram grandes fornecedores de crédito. $\mathrm{O}$ capitão Francisco José da Silva, dono de uma venda instalada no térreo de um sobrado em Uberaba, em 1837, tinha um rol de 91 devedores, que somavam 
A Oeste das Minas

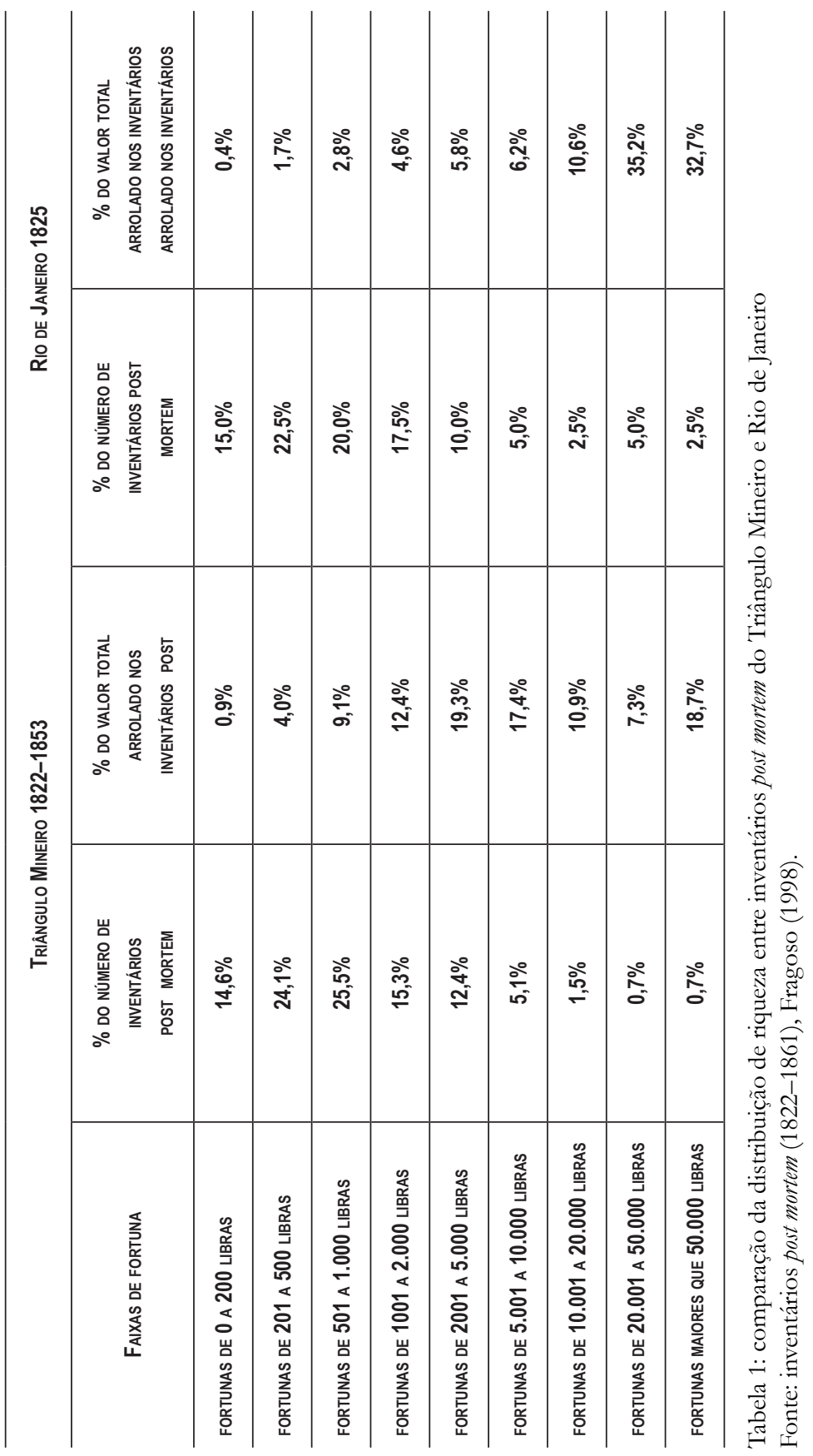


1:323\$050, ou $24 \%$ de seu patrimônio. ${ }^{16}$ Referia-se pequenos valores, variando de um a 20 mil-réis, de miudezas compradas fiadas pela sua clientela. Essa parecia ser a única forma de crédito oferecida por esses vendeiros e mascates.

Apesar dessas diferenças em relação ao que se via na Corte — fazendeiros, e não comerciantes, como agentes do capital usurário; pouca relevância da classe mercantil no processo de acumulação local; ausência de grandes capitais mercantis na região —, havia vários traços comuns entre o Triângulo Mineiro da primeira metade do século XIX e outras regiões do Brasil, inclusive o Rio de Janeiro. Se a concentração de riqueza era um desses traços, outro era o caráter restrito do mercado, isto é, um volume de trocas pequeno frente ao consumo total.

Isso ocorria porque, no Rio de Janeiro, e ainda mais no sertão do Extremo Oeste Mineiro, havia grandes limitações à mercantilização geral, típica de economias capitalistas. Não existia aqui um mercado regulado por mecanismos endógenos de feedback, impulsionadores de uma dinâmica "natural", como a descrita pelos economistas liberais clássicos. Vimos que as relações de trabalho escravistas, por exemplo, necessitavam de mecanismos de coerção extra-econômica que se formavam fora do mercado. Na ausência da força de trabalho como mercadoria, não existe um mercado consumidor formado pelos trabalhadores, mas, no lugar dele, um mercado muito mais restrito formado pelos proprietários escravistas comprando víveres.

O próprio mercado de víveres formado pelos proprietários de escravos seria ainda mais restrito, se se levar em conta a brecha camponesa, isto é, a agricultura de subsistência própria do escravo, praticada nos finais de semana com a anuência dos senhores. Segundo Cardoso (1988), ela seria estrutural ao escravismo brasileiro, hipótese que ainda carece de comprovação.

No Triângulo Mineiro, a existência de uma larga parcela de trabalho camponês - e camponês com escravos - também contribuía para tornar ainda mais restrito o mercado local. Grande parte da demanda das famílias camponesas e de seus escravos era suprida pela produção doméstica de autoconsumo. Mesmo quando se necessitava recorrer ao mercado para obtenção de algum gênero de subsistência, ele geralmente podia ser encontrado nos mercados locais, representados pelos arraiais. Além disso, havia um baixo nível de especialização e uma divisão social do

16 APU, Inventário de Francisco José da Silva (09/02/1837), maço 6, caixa 460. 
trabalho muito restrita entre as unidades produtivas. Em outras palavras, todos produziam mais ou menos as mesmas coisas, criando muito poucas oportunidades de trocas.

Outra característica desse mercado restrito era o baixo nível de liquidez da economia. Fragoso (1998) demonstrou a pequena presença de moedas nos inventários post mortem do Rio de Janeiro, dos primeiros anos do século XIX: totalizavam menos de 5\% do valor das fortunas inventariadas. Silveira (1997) evidenciou que, mesmo na região aurífero-metalúrgica de Minas, no século XVIII, onde o ouro em pó funcionava como moeda, havia insuficiência de meios de circulação. A obtenção de crédito, numa situação de endividamento generalizado, era a única forma de expandir os negócios para a maioria dos mineiros. Em nosso estudo, verificamos que o patrimônio na forma dinheiro somava apenas $7: 518 \$ 480$, ou $0,7 \%$ do valor total inventariado.

Assim, apesar das grandes diferenças culturais, de urbanização, de organização da produção, de nível de acumulação e de especialização regional do trabalho, existiam traços comuns à sociedade carioca, à mineira da região aurífera-metalúrgica e à triangulina, e que arrolamos a seguir:

- Hierarquia econômico-social fortemente diferenciada.

- Presença do capital usurário com endividamento eneralizado.

- Baixo nível de divisão social do trabalho.

- Mercados restritos e instáveis.

Tais características, segundo Fragoso,

se identificam com aqueles descritos por W. Kula e Fernand Braudel para o mercado pré-industrial europeu, assim como se aproximam das características mais gerais, analisadas por C. Mourim, para o circuito mercantil colonial do México para o século XVIII. Desse modo, a existência de um mercado restrito, baseado numa frágil divisão social do trabalho e numa precária circulação de mercadorias, inclusive moedas, onde se verificam práticas monopolistas, especulativas e a usura, não é privilégio do circuito mercantil do Sudeste-Sul brasileiro. Tais traços são atinentes àquilo que normalmente se denomina de mercado pré-capitalista (1998, p. 185). 
Cada vez mais, parece firmar-se um consenso entre grande parte dos autores da moderna historiografia ${ }^{17}$ de que as práticas e instituições do Brasil Colônia (e do Brasil sob a Casa de Bragança) foram o resultado da economia e da cultura política do Antigo Regime português, e como tal se inscreviam no quadro geral das sociedades pré-capitalistas de então.

O Triângulo Mineiro da primeira metade dos Oitocentos parece confirmar essa idéia, a despeito de ter sido, nesse tempo, uma região de povoamento pioneiro. Acreditamos, desse modo, que, ao se entender a economia e a sociedade criadas no processo de colonização dessa região, podese revelar um pouco da dinâmica de uma área de fronteira não capitalista do Antigo Regime.

Os elementos que até aqui discutimos, se servem para esboçar o pano de fundo sobre o qual se desenvolveu a economia agropastoril do Triângulo Mineiro, em princípios do século XIX, não dão conta de algumas especificidades como, por exemplo, diferenças entre proprietários e não-proprietários de terra, chacareiros e sitiantes, criadores e invernistas de gado. Além disso, as relações de trabalho que então se reproduziam não podem ser compreendidas apenas a partir da dicotomia simplificadora senhor/escravo. Nossas fontes permitiramnos entrever um mundo muito mais complexo do que esse, no qual coexistiam camponeses proprietários, camponeses agregados, camponeses com escravos, pequenos, médios e grandes escravistas. No item que se segue, entenderemos como essa sociedade reiterava suas relações com a terra e com o trabalho.

\section{Propriedade e posse da terra}

Numa tentativa de compreender as relações sociais e econômicas do Triângulo Mineiro na primeira metade do século XIX, faremos, mediante os inventários post mortem, três classificações diferentes dos fogos. A primeira delas se fundamentará na posse e propriedade sobre bens de raiz; a segunda, na posse de escravos e na razão trabalho familiar/trabalho cativo; e a terceira, no tamanho dos rebanhos e na presença (ou ausência) de atividades produtivas especializadas em cada um dos fogos. Ensaiaremos, a partir daí, algumas

17 Ver, por exemplo, Fragoso Bicalho e Gouveia (2001). 
tipologias que possam dar conta da complexidade das relações de propriedade, de trabalho e de dependência da população da região no período.

Qualquer análise da estrutura fundiária e da dinâmica de ocupação e uso da terra, no período colonial e imperial, deve levar em conta que o acesso a ela, naquela época, estava submetido a um ordenamento jurídico diferente dos dias atuais. Mesmo após a Lei de Terras de 1850, que acabou com a posse livre de terras e a tornou acessível somente por meio da compra, era possível a um produtor estabelecer-se em propriedades alheias, mediante arrendamento ou pagamento do foro, ou mesmo sem ônus e com a permissão do proprietário, nesse caso, tornando-se, como vimos no capítulo anterior, um agregado. ${ }^{18}$

$\mathrm{O}$ aforamento parecia ser mais freqüente em regiões de maior valorização fundiária e maior densidade demográfica, como o litoral norte do Rio de Janeiro (FARIA, 1998), o mesmo se dizendo do arrendamento, como a Zona da Mata nordestina (Ferlini, 1988). Já na região do Triângulo Mineiro, a posse sem ônus, em terras de terceiros, era a forma mais comum pela qual produtores sem terra se estabeleciam. Aqui, o aforamento era mais comum em terras dos patrimônios religiosos, nos arraiais.

No período em questão, havia também um mercado de situações, isto é, a possibilidade de compra, venda e herança de sítios com suas benfeitorias erguidos em terras de terceiros. A situação era reconhecida como um bem independente da terra, podendo ser livremente negociado e sendo objeto de partilhas (Fragoso, 1998). Havia, portanto, a possibilidade de posse estável sem propriedade de terras, mesmo que estas nominalmente pertencessem a terceiros.

Outras duas formas de posse fundiária presentes no período em questão, e que nos interessam no caso específico do Triângulo Mineiro oitocentista, eram o aforamento de terras do patrimônio religioso e as chácaras. O aforamento de chãos de terra (pequenos lotes), com autorização das autoridades eclesiásticas, era a principal forma de obtenção do "solo urbano", já que os arraiais se desenvolviam em

18 Usaremos esse termo como sinônimo de posseiros vivendo em terra alheia, com permissão do proprietário e dependente deste. Esse é o sentido empregado por Saint Hilaire, em sua viagem pela região em 1819 (1975 a; 1975 b) e também por Antônio Cândido (2001), embora Marcílio (2000) afirme que, até o século XVIII, a palavra agregado só fosse empregada para moradores que vivessem sob o mesmo teto do proprietário, sem laços de parentesco com o mesmo. Porém a autora admite que o termo passou a ser empregado a partir do século XIX referindo-se a sitiantes vivendo em terra alheia, sem ônus. Por isso, usaremos a palavra agregado com esse sentido. 
torno de capelas construídas sobre terras doadas à Igreja. Discutiremos a economia e a geografia urbana dos arraiais triangulinos no próximo capítulo.

As chácaras eram situações que ocupavam um status interessante. Também resultavam do aforamento de terras do patrimônio dos arraiais (ou do rocio das vilas), mas localizavam-se à distância do centro dessas localidades, na periferia das terras foreiras. Dessa forma, todo arraial dispunha de um cinturão de chácaras, organizado em torno do núcleo formado pelo adro da capela e pelo arruamento que dele partia (Murilo Marx, 1991). Nelas se constituíam pequenas unidades produtivas, em escala menor que nos sítios e fazendas.

A partir da descrição pormenorizada que, via de regra, os inventários post mortem traziam dos bens de raiz, foi possível agrupá-los numa classificação baseada no tipo de posse ou propriedade fundiária. Com base nisso, criamos os seguintes grupos:

- Proprietários: reunimos aqui todos os inventários que declararam fazendas ou sortes de terras. Como os limites fundiários eram muito imprecisos, usamos o preço da terra como critério para a divisão dos proprietários em subgrupos, segundo o valor da propriedade. Assim, os proprietários de terras com valor até um conto de réis eram aqueles que possuíam aproximadamente até 500 alqueires (na proporção média de 2 alqueires de campos para cada alqueire de cultura), o que, no contexto do caráter extensivo das práticas de então, tratavam-se de pequenas propriedades. ${ }^{19}$ Os proprietários entre 1:000\$000 a 3:000\$000 possuíam extensões que variavam de 500 a 1.500 alqueires; entre 3:000\$000 e 5:000\$000, de 1.500 a 2.500 alqueires; e mais de 5:000\$000, maiores de 2.500 alqueires. Estes últimos formavam o grupo dos grandes proprietários.

- Sitiantes: este grupo era formado por aqueles que possuíam situações (isto é, benfeitorias como casa de morada, currais, paióis, monjolos, quintais com árvores frutíferas etc.), mas não eram proprietários das terras onde elas se encontravam.

- Agregados sem sítios: agrupamos aqui aqueles que, não obstante não possuírem bens de raiz, tinham escravos, gado, milho estocado, ferramentas de roça e

19 Levando-se em conta que o preço do alqueire de cultura era de aproximadamente $4 \$ 000$, e dos campos de $1 \$ 000$, e supondo-se uma proporção aproximada de 2 alqueires de campo para cada alqueire de cultura. 
outros equipamentos que demonstravam a existência de trabalho na terra. Supomos que se tratava do grupo, certamente numeroso, de agregados, que trabalhavam em terras de terceiros e viviam em arranchações de taipa sem valor — e que, por isso, não eram inventariadas — ou viviam em moradias cedidas ou alugadas por fazendeiros.

- Chacareiros: aqui, reunimos os que tinham chácaras como único bem de raiz rural. Embora fosse comum grandes fazendeiros manterem chácaras na periferia dos arraiais, existia um grupo de chacareiros exclusivos, bem mais pobres que esses.

- Moradores dos arraiais: aqui, agrupamos aqueles que tinham nos imóveis localizados nos arraiais seu único bem de raiz. Formavam a parcela mais pobre da população, e serão objeto do próximo capítulo.

Assim sendo, a distribuição dos inventariados segundo o tipo de propriedade pode ser vista no gráfico 5. Como se pode notar, os pequenos proprietários eram a maioria simples da população inventariada, somando 31\% do total. Os agregados sem sítio formavam o segundo grupo mais numeroso, com 19\% do total. Os grandes proprietários somavam apenas $9 \%$ do total dos inventários.

A distribuição de riqueza entre os grupos pode ser vista no gráfico 6 . Nele se pode ver que os grandes proprietários de terra, apesar de formarem apenas $9 \%$ da população inventariada, concentravam $51 \%$ da sua riqueza. Com isso se comprova não só a forte hierarquização econômica, mas também que a elite regional era formada pelos grandes proprietários fundiários. Na outra ponta da escala social, encontramos os pequenos proprietários, que somavam $31 \%$ da população, mas controlavam só $10 \%$ da riqueza inventariada, e os agregados sem sítio, $19 \%$ da população, mas com apenas $4 \%$ da riqueza bruta.

O perfil econômico dos grupos pode ser desvendado pela posse média de cativos e de rebanhos em cada um deles, conforme é visto nas tabelas 2 e 3. A distribuição da posse mancípia, na tabela 2, revela o que Libby (1988) já havia sugerido existir em toda a província de Minas Gerais: a pulverização da posse de escravos entre vários grupos sociais, inclusive pequenos proprietários e agregados. Até mesmo a parcela mais pobre da população inventariada, os moradores dos arraiais, tinham em média dois escravos. Tratava-se do que esse autor chamou de "posse democrática" de escravos: o senhor de grandes escravarias de modo algum era a figura que dominava a paisagem social. 


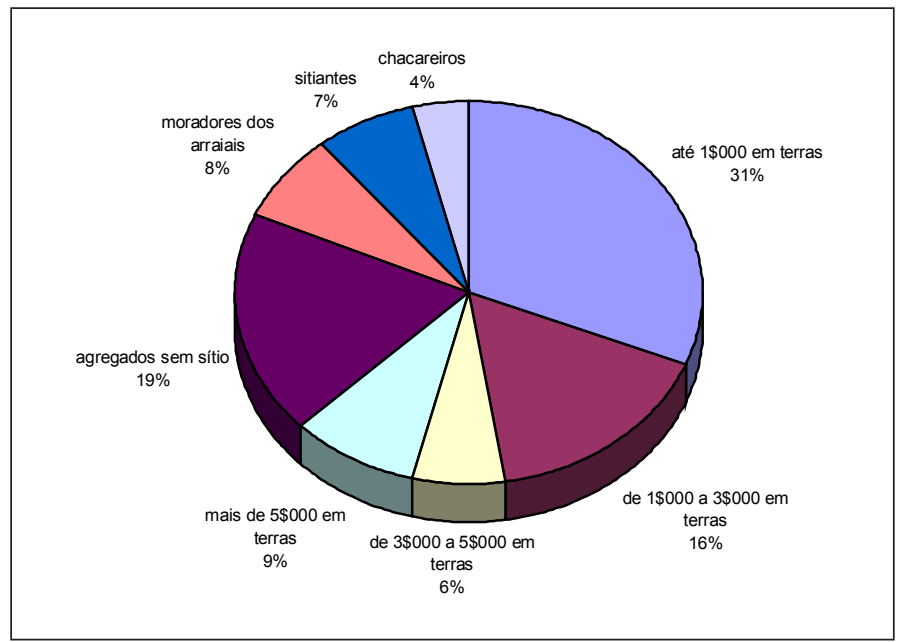

Gráfico 5: distribuição dos inventários post mortem (em \%) segundo o tipo de propriedade no termo de Uberaba (1822-1861)

Fonte: APU, inventários post mortem (1822-1861).

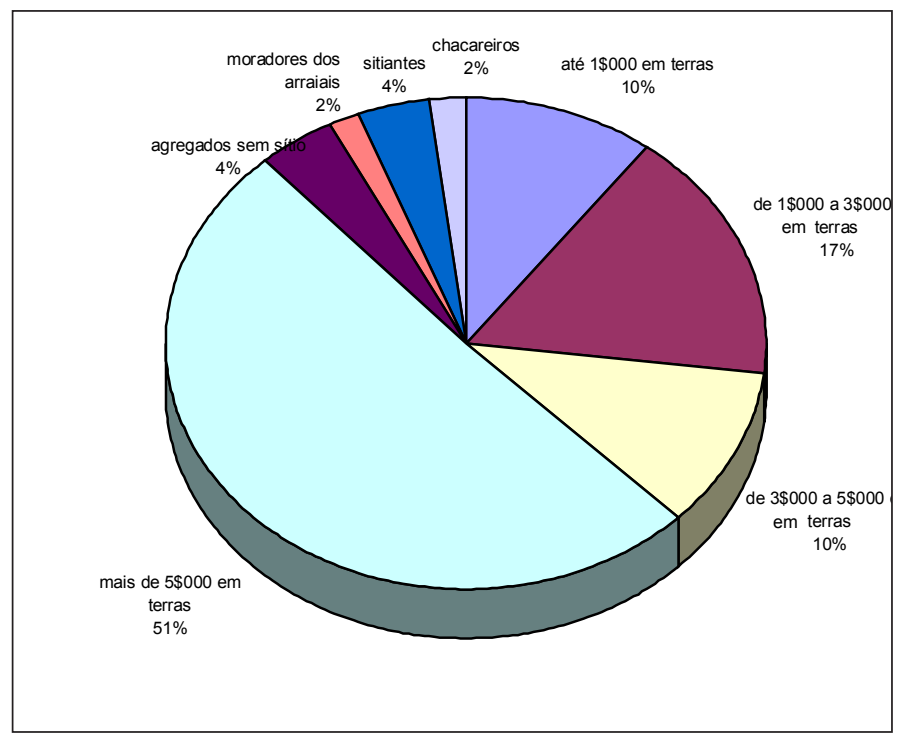

Gráfico 6: distribuição da riqueza inventariada total (em \%) segundo o tipo de propriedade fundiária, no termo de Uberaba (1822-1861).

Fonte: APU, inventários post mortem (1822-1861). 
Por outro lado, a mesma tabela revela uma forte concentração da posse mancípia, como de resto acontecia com todas as outras formas de riqueza: enquanto pequenos proprietários e agregados possuíam em média de dois a três escravos, a média dos latifundiários (mais de 5:000\$000 em terras) era de mais de 19 escravos.

A tabela revela uma correlação positiva entre tamanho da propriedade e plantel médio de escravos, o que pode ser mais bem visualizado no gráfico 7. Comprova-se, assim, como já havíamos sugerido antes, que escravos e terra eram não só as principais formas de acumulação, mas também os principais meios de reprodução de riqueza nessa sociedade, dados o baixo nível técnico das práticas vigentes (e a quase ausência de bens de capital) e a inexistência do grande capital mercantil.

A posse de rebanhos (tabela 3) também revela a concentração dos plantéis bovinos e, ao mesmo tempo, mostra que a criação de gado estava presente em

\begin{tabular}{l|c}
\hline NúMERO MÉdIO DE ESCRAVOS & \\
\hline MAIS DE 5\$000 EM TERRAS & 19,4 \\
\hline DE 3\$000 A 5\$000 EM TERRAS & 9 \\
\hline DE $1 \$ 000$ A 3\$000 EM TERRAS & 6,5 \\
\hline ATÉ $1 \$ 000$ EM TERRAS & 2,9 \\
\hline CHACAREIROS & 5,2 \\
\hline SITIANTES & 3,2 \\
\hline AGREGADOS SEM SÍTIO & 2,6 \\
\hline MORADORES DOS ARRAIAIS & 2 \\
\hline
\end{tabular}

Tabela 2: número médio de escravos por tipo de unidade, em Uberaba (1822-1861). Fonte: APU, inventários post mortem (1822-1861).

todos os extratos sociais. De fato, até mesmo os moradores dos arraiais e os agregados sem sítios dispunham de um pequeno rebanho de 10 a 14 cabeças, em média. Esses pequenos rebanhos eram formados, predominantemente, por vacas de criar e bois de carro. Por exemplo, o agregado Clemente José Ferreira, que, em 1835, também exercia o ofício de ferreiro, provavelmente alugava pastos 
ou contava com a concessão paternalista de algum grande proprietário, que lhe cedesse campos, para manter seu pequeno rebanho de quatro bois de carro, dez vacas paridas e seis novilhas solteiras. É possível que obtivesse vinte litros de leite por dia com suas vacas, com o que alimentava seus filhos e talvez fizesse queijos. Para levá-los e às suas ferrarias ao arraial de Uberaba, para vendê-los, ele, sua esposa, seus filhos e a jovem escrava Eva, de 14 anos, contavam com um carro, puxado pelas suas duas juntas de bois. ${ }^{20}$

$\mathrm{Na}$ outra ponta da escala social, encontravam-se os proprietários de fazendas de mais de cinco contos de réis, que possuíam em média mais de trezentas cabeças. Apesar de, nesse grupo, existirem grandes criadores, as atividades de recria e engorda eram as que mais interessavam aos fazendeiros ricos. Os gráficos 8 e 9, relativos a períodos diferentes, mostram a mesma tendência: quanto maior o rebanho, maior o percentual do plantel na forma de garrotes e novilhas de um a quatro anos.

\begin{tabular}{l|c}
\hline REBANHOS & \\
\hline MAIS DE $5 \$ 000$ EM TERRAS & 381,71 \\
\hline DE 3\$000 A 5\$000 EM TERRAS & 87,50 \\
\hline DE $1 \$ 000$ A 3\$000 EM TERRAS & 86,65 \\
\hline ATÉ 1\$000 EM TERRAS & 31,98 \\
\hline CHACAREIROS & 18,33 \\
\hline SITIANTES & 40,91 \\
\hline AGREGADOS SEM SÍTIO & 14,00 \\
\hline MORADORES DOS ARRAIAIS & 10,42 \\
\hline
\end{tabular}

Tabela 3: número médio de cabeças de gado por tipo de unidade no termo de Uberaba (1822-1861).

Fonte: APU, inventários post mortem (1822-1861).

Desse modo, o que parece se revelar é que a atividade de recria e engorda, que exigia relativa disponibilidade de capital circulante para a aquisição de bezerros, era realizada preferencialmente pelos mais ricos. Por

20 APU, Inventário de Clemente José Ferreira (7/12/1835), maço N37. 


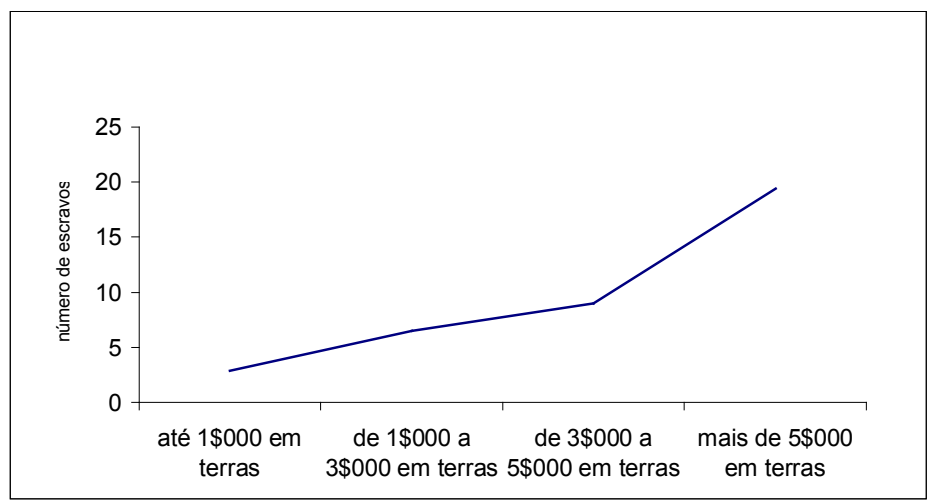

Gráfico 7: correlação entre propriedade de terras e propriedade de cativos no termo de Uberaba (1822-1861)

Fonte: APU, inventários post mortem (1822-1861).

outro lado, a atividade de criação, que não exigia inversões significativas, mas apenas a reprodução natural do gado, sob os cuidados dos membros da família e de alguns escravos, era a atividade praticada usualmente pelos pequenos.

Nos testemunhos deixados pelos cronistas joaninos, podemos confirmar a existência da atividade de engorda de gado como especialidade de alguns pecuaristas. Ao tempo de Eschwege, em Araxá, alguns fazendeiros eram criadores de bezerros, vendidos com um ano de idade para fazendas de invernada e, após a engorda, eram revendidos aos compradores de São João Del Rei:

Na Fazenda Morro Alto [...] fomos acolhidos cordialmente por dois irmãos que [...] dedicavam-se especialmente ao comércio do gado. Compram bois de um ano e vendem-no para o Rio de Janeiro, aos quatro anos (EsCHWEGE, 1996, p. 108-109).

Nos anos posteriores a 1830, também Uberaba passou, de forma crescente, a desempenhar esse papel de centro de invernada para a região.

Assim como os demais tipos de riqueza, também o gado, que era a principal forma pela qual o excedente da região era realizado no mercado extra-regional, tendia a concentrar-se nas mãos de uma elite de grandes fazendeiros. O gráfico 10 mostra a distribuição dos criadores, divididos por categorias segundo o 


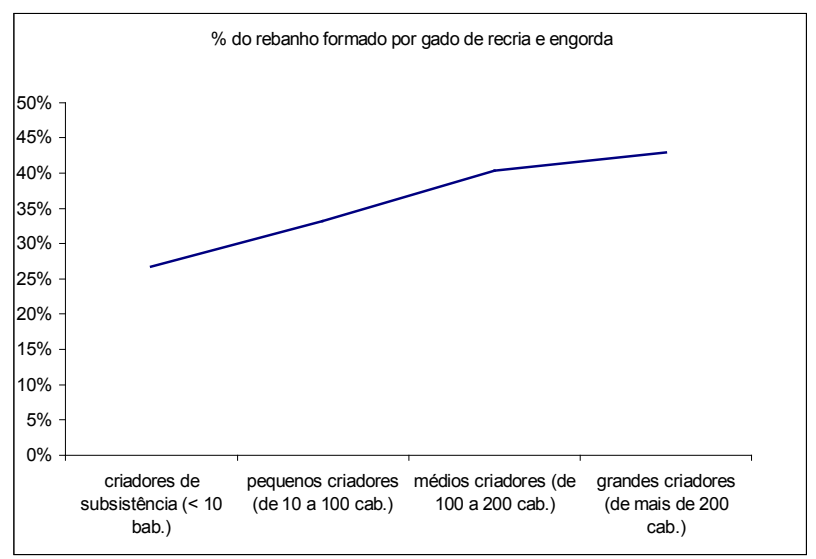

Gráfico 8: porcentagem do rebanho formado por gado de recria e engorda (garrotes maiores que 1 ano e menores que 4 anos), por categoria de criadores, no termo de Uberaba (1822-1841). Fonte: APU, inventários post mortem (1822-1861).

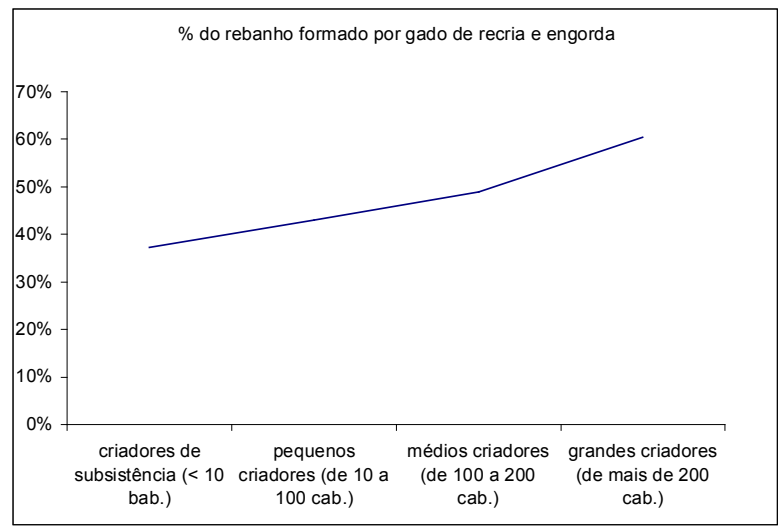

Gráfico 9: porcentagem do rebanho formado por gado de recria e engorda (garrotes maiores que 1 ano e menores que 4 anos), por categoria de criadores, no termo de Uberaba (1842-1861). Fonte: APU, inventários post mortem (1822-1861). 
tamanho dos plantéis, e o gráfico 11 mostra a distribuição do rebanho total da região em cada uma dessas categorias. Os pequenos criadores (10 a 100 cabeças de gado), apesar de constituírem $61 \%$ dos fazendeiros de gado, possuíam só $25 \%$ do rebanho da região. Já os grandes criadores (mais de 200 cabeças de gado), apesar de serem $7 \%$ dos fazendeiros, controlavam 55\% dos rebanhos da região.

As categorias que criamos, baseadas no acesso à terra, guardam uma certa correlação com outras formas de riqueza: quanto maior a propriedade fundiária, mais escravos e gado. Mas não se trata, contudo, de uma correlação absoluta. Como mostram as tabelas 2 e 3 , por exemplo, os sitiantes, que não tinham a propriedade e sim o usufruto da terra, possuíam em média mais escravos, e rebanhos mais numerosos, que os pequenos proprietários de terra. O grupo dos sitiantes era, aliás, o mais heterogêneo de todos. Nele se podem encontrar desde agricultores pobres, como Pedro José da Silva que, em 1853, vivia numa casa com curral e um paiol, sem escravos e apenas com uma vaca e um cavalo velho; ${ }^{21}$ até senhores de razoável cabedal, como Jorge de Abreu Castello Branco que, em 1860, possuía um sítio em terra alheia, na Fazenda do Veríssimo, com 14 escravos e 181 cabeças de gado, além de uma tropa com oito burros. ${ }^{22}$

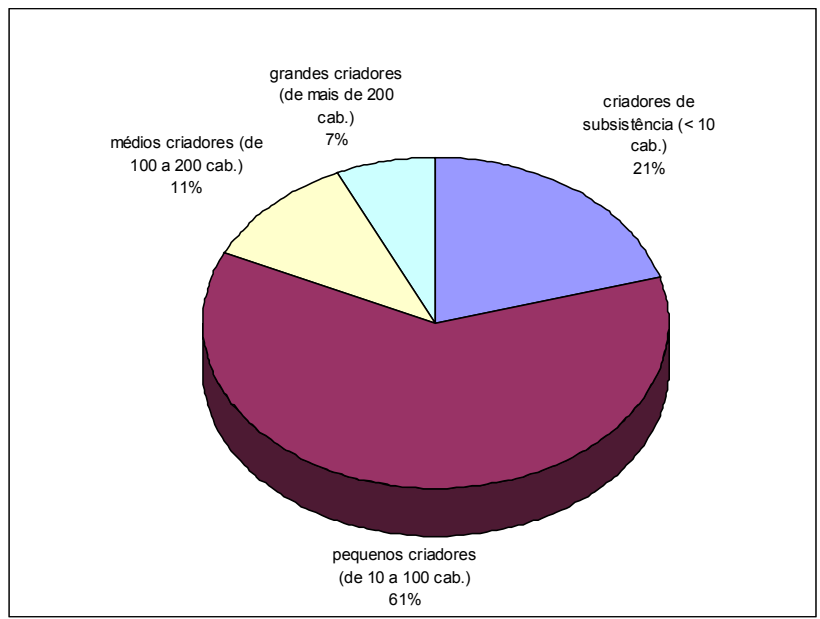

Gráfico 10: \% do número total de criadores de gado, por número de cabeças, no termo de Uberaba (1822-1861)

Fonte: APU, inventários post mortem (1822-1861).

21 APU, inventário de Pedro José da Silva (24/10/1853), maço N14.

22 APU, inventário de Jorge de Abreu Castello Branco (18/04/1860), maço N15, caixa 470. 
Os aspectos que identificamos para cada categoria baseiam-se na média de cada uma delas, mas as variações de caso a caso eram muito grandes. Não podemos a princípio, com base no critério do acesso à terra, distinguir, por exemplo, um proprietário escravista de um camponês, embora possamos afirmar que geralmente existia uma correlação entre acesso à terra e posição na hierarquia social. Isso ocorre porque o status social de um indivíduo dependia de um conjunto de fatores, dos quais a propriedade fundiária era apenas um deles. No contexto de uma economia rural, como a do Triângulo Mineiro oitocentista, a posse de escravos é uma variável muito mais importante na tentativa de apreender como se organizavam os grupos sociais coevos.

Dessa forma, se a aquisição de escravos era a principal configuração assumida pela riqueza acumulada, em qualquer grupo de proprietários, o tráfico de escravos era a principal forma pela qual o excedente, gerado na região, era drenado para outras partes do Brasil. Faremos a seguir, com base em nossas fontes, uma estimativa do tráfico negreiro no termo de Uberaba, na primeira metade do século XIX.

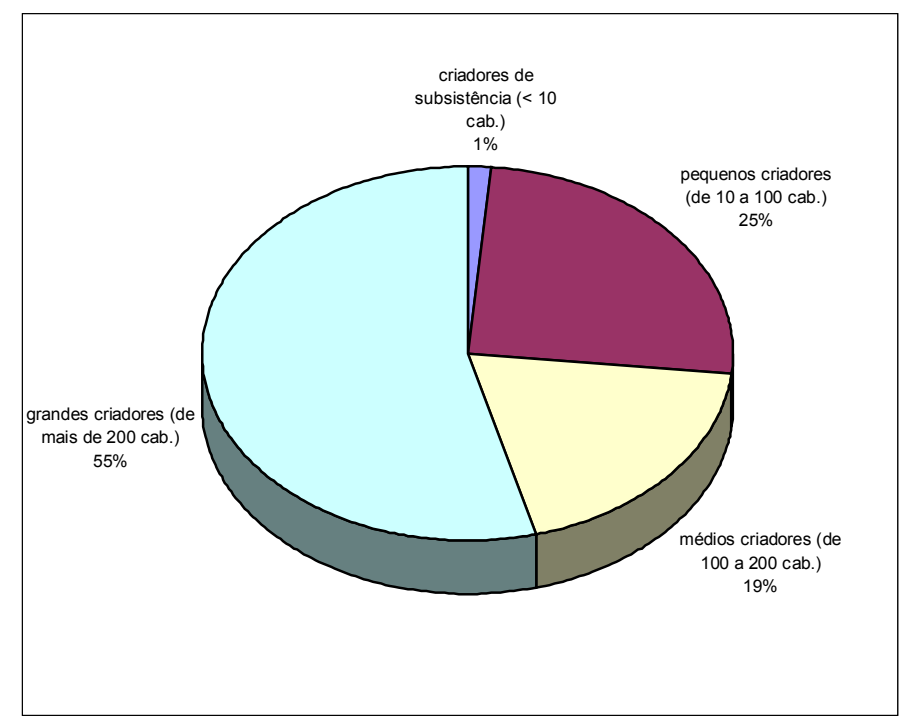

Gráfico 11: \% do rebanho da região, dividido por categoria de proprietários, no termo de Uberaba (1822-1861).

Fonte: APU, inventários post mortem (1822-1861). 


\section{O tráfico negreiro}

O estudo do tráfico negreiro é uma maneira de estimar, indiretamente, a capacidade de acumulação da economia local. Como vimos no tópico anterior, escravos eram a principal forma pela qual a riqueza era acumulada na região, tanto entre pequenos sitiantes quanto grandes fazendeiros. A maior parte do excedente realizado no mercado era usado, portanto, na aquisição de cativos.

O tráfico de escravos para Minas Gerais era feito pelas tropas vindas do Rio de Janeiro, embora o Triângulo Mineiro também recebesse, provavelmente, escravos trazidos pelas tropas paulistas. Os tropeiros especializados no tráfico terrestre eram chamados comboieiros (figura 1), mas, segundo Fragoso (1998), eram minoritários no tráfico para a província. Os estudos desse autor, que tiveram por base os Registros de Saída de Tropeiros do Rio de Janeiro, revelam que o traficante eventual - tropeiros que conduziam um a dois escravos por tropa, junto com outras mercadorias - era a regra no comércio terrestre de escravos em Minas Gerais. Na série analisada pelo autor, somente 19 traficantes $(0,3 \%$ do total) podiam ser classificados como negociantes regulares de cativos. Mesmo estes não levavam grandes cargas negreiras: em média, conduziam 5,9 cativos por tropa:

Em vista desses números, podemos dizer que o tráfico de escravos era feito através de pequenos empreendimentos. Mais do que isso, por condutores que eventualmente (talvez conjunturalmente seja o mais correto) transportavam escravos. Estaríamos, assim, diante de um negócio que, devido à eventualidade de seus agentes, não era especializado; não contava com um grupo permanente de empresários (Fragoso, 1998, p. 207).

É provável, portanto, que a tropa descrita por Saint Hilaire na Estrada do Anhanguera, a caminho do Cuiabá, levando doze cativos, tenha sido mais exceção do que regra, no tráfico de escravos para o interior do Brasil:

Conversei com o mercador a quem pertencia essa tropa e ele me disse que era composta de sessenta bestas de carga. Levava também uma dúzia de molecotes da Costa da África, e estava vindo de São Paulo com destino a Cuiabá (1975 a, p. 120). 
Usando os inventários post mortem como fontes, podemos estimar indiretamente a intensidade do tráfico para a região e, por conseguinte, a própria capacidade de acumulação da economia regional. Os inventários, agrupados em séries divididas por períodos, dão espaço a análises diacrônicas sobre o perfil dos plantéis — taxas de masculinidade, africanidade e pirâmides etárias - o que permite algumas inferências, embora aproximadas, sobre o tráfico negreiro.

Gorender (1988) demonstrou que, em regiões mais ricas, a taxa de masculinidade escrava ultrapassava, em muito, os $50 \%$ da população cativa

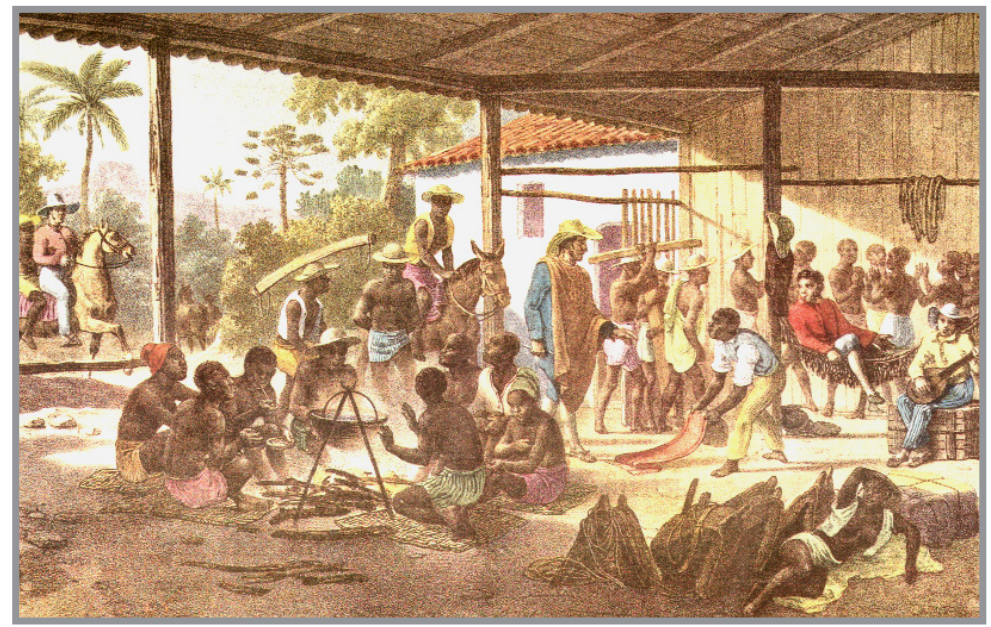

Figura 1: comboio de negros.

Fonte: Rugendas (1998).

total. Isso se devia à tendência de os senhores de escravos preferirem homens jovens para compor seus plantéis. Os desembarques negreiros no porto do Rio de Janeiro, estudados por Florentino e Góes (1997), com base nos dados relativos a africanos negociados no mercado do Valongo, entre 1822 e 1833, já traziam, desde a África, esse desequilibrio entre os sexos e as idades. Segundo os autores, os homens de idade entre 15 a 25 anos representavam algo em torno de $40 \%$ do total de escravos desembarcados na capital do Império. 
A alta taxa de masculinidade, evidentemente, tendia a desaparecer com a primeira geração de escravos crioulos, caso a população escrava não fosse renovada pelo tráfico. Dessa forma, a persistência de uma alta taxa de masculinidade, ao longo do tempo, é demonstrativa da presença do tráfico em atividade e, portanto, de capacidade de acumulação. Na região do Triângulo Mineiro, a taxa de masculinidade, calculada por meio dos plantéis constantes nos inventários post mortem, variou de 62\%, de 1822 a 1841, a 54\%, de 1842 a 1851. Esses números parecem mostrar, com a queda da taxa de masculinidade, uma redução do tráfico negreiro no período, e uma dependência maior da taxa de natalidade escrava, na renovação da força de trabalho.

Da mesma forma, a taxa de africanidade — percentual do plantel formado por africanos — também é valiosa para se estimar a intensidade do tráfico. Nos documentos estudados, foram arrolados 534 escravos, de 1822 a 1851, um ano depois da extinção do tráfico transatlântico. A taxa de africanidade em Uberaba, calculada sobre essa amostra, variou de 34,35\%, no período $1822-1841$, a 30,64\%, no período 1842-1851. Estes dados demonstram a presença de tráfico ativo na região e, deste modo, de relações mercantis intensas com as cidades portuárias. Mas mostram também uma pequena queda da taxa no período, devendo-se, provavelmente, ao inflacionamento do preço do escravo, com retração do mercado.

Uma análise ainda mais precisa dos efeitos do tráfico sobre os plantéis uberabenses pode ser obtida comparando-se as pirâmides etárias dos escravos, separados em africanos e crioulos, ao longo desse período. O gráfico 12, que mostra a pirâmide etária da população africana entre 1822 e 1841, demonstra a presença maciça de homens jovens — entre 11 e 30 anos —, o que é uma prova indireta da atividade do tráfico, a partir dos portos negreiros.

O gráfico 13, que exibe a pirâmide etária de africanos do período seguinte, de 1842 a 1851, já às vésperas da extinção do tráfico transatlântico, revela um envelhecimento daquela população, se comparada com a do período anterior. Isso evidencia que, com a proximidade da proibição do tráfico, a repressão britânica aos negreiros no Atlântico, e o conseqüente aumento do preço dos escravos importados, houve redução da importação de africanos pela região.

As pirâmides etárias da população crioula (gráficos 14 e 15) mostram perfis tipicamente pré-malthusianos, representativos não só da alta mortalidade, mas também da alta natalidade entre os escravos. Além disso, vê-se também uma simetria na distribuição entre os sexos, provando que a taxa de masculinidade 
entre eles era próxima à da população livre.

Esses dados parecem indicar, na falta de registros diretos da atividade do tráfico de escravos na região, que parte significativa do excedente gerado nas atividades econômicas era drenado para as mãos dos negociantes negreiros, fossem eles tropeiros ou mercadores do litoral.

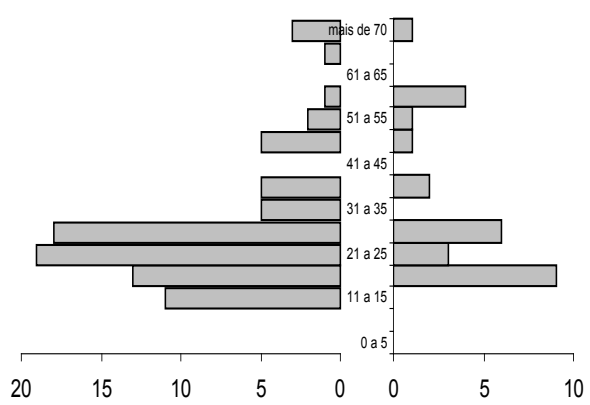

Gráfico 12: pirâmide etária da população escrava africana, no termo de Uberaba, entre 1822 e 1841.

Fonte: APU, inventários post mortem (1822-1841).

Num contexto de inexistência de um capital mercantil autóctone, de quase ausência de relações de trabalho assalariadas, e no qual quase toda riqueza era imobilizada em terra e escravos, a força de trabalho assumia predominantemente duas formas: trabalho familiar e trabalho cativo. Veremos a seguir como se estratificava a sociedade triangulina com base no recurso a essas formas de trabalho.

\section{Trabalho familiar e trabalho escravo}

Em seu trabalho sobre a economia mineira do século XIX (aliás pioneiro sobre o assunto), Libby (1988) utilizou os mapas da população, feitos pelo governo provincial entre 1831 e 1840, para estudar a distribuição da posse de cativos em toda a província. O autor percebeu que, em Minas Gerais, existiam no período dois padrões regionais distintos de distribuição da propriedade mancípia: um fortemente concentrado, e outro que exibia o que chamou de "posse democrática" de escravos. 
A concentração na posse de cativos, segundo o autor, ocorria em três regiões: Zona da Mata, Metalúrgica-Mantiqueira e Triângulo Mineiro. No primeiro caso, os grandes plantéis (mais de 30 escravos) concentravam $27 \%$ do total da população cativa, o que se explica pelo avanço, a partir dos anos 1820, da cafeicultura em sistema de plantation na região. Na zona

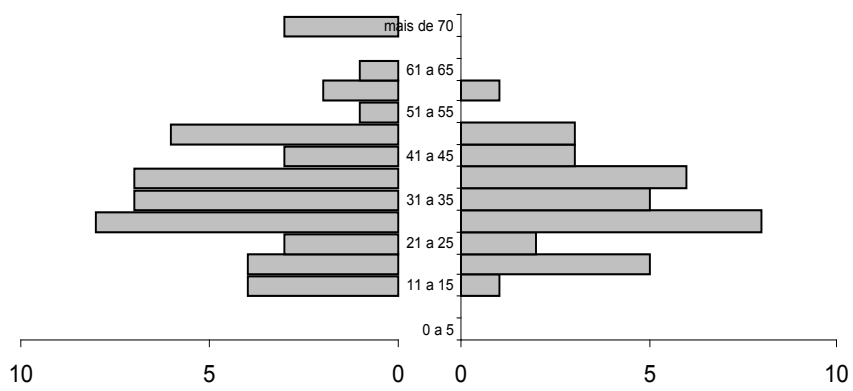

Gráfico 13: pirâmide etária da população escrava africana, no termo de Uberaba, entre 1842 e 1851.

Fonte: APU, inventários post mortem (1842-1851).

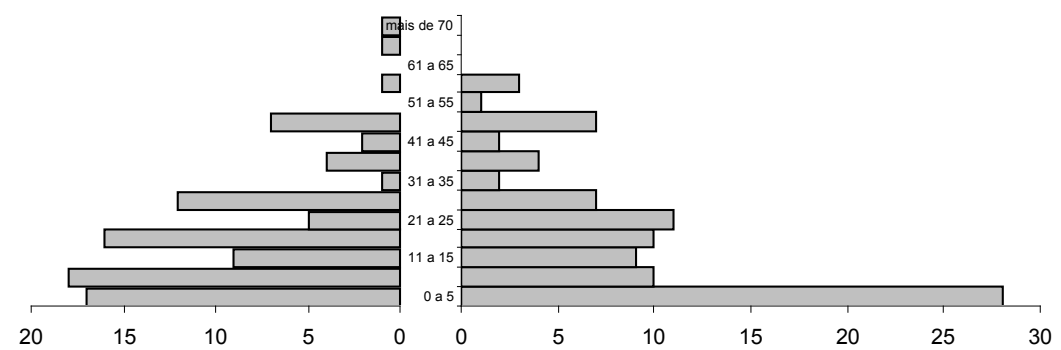

Gráfico 14: pirâmide etária da população escrava crioula, no termo de Uberaba, entre 1822 e 1841. Fonte: APU, inventários post mortem (1822-1841). 


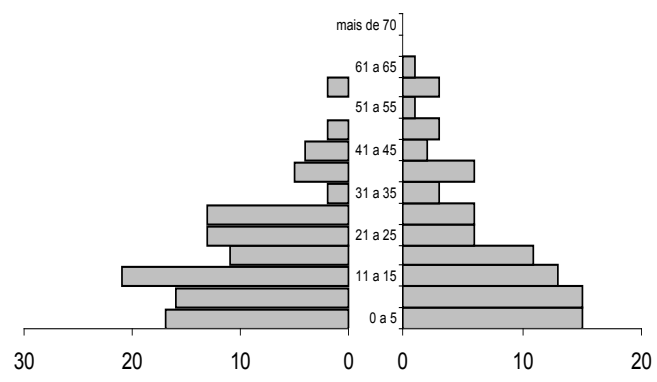

Gráfico 15: pirâmide etária da população escrava crioula, no termo de Uberaba, entre 1842 e 1851. Fonte: APU, inventários post mortem (1842-1851).

Metalúrgica-Mantiqueira, as grandes escravarias, que representavam $32 \%$ da população escrava da região, deviam-se à presença das grandes mineradoras de capital britânico, que extraíam ouro em profundidade, como a Imperial Brazilian Mining Association (Gongo Soco) e a Saint John Del Rei Mining Company (Morro Velho), e que chegavam a empregar mais de 300 escravos em suas atividades. Quanto à última região, diz o autor:

Quanto ao Triângulo Mineiro, não podemos oferecer nenhuma explicação para a desconcentração lá registrada, pois o perfil da região não destoa dos padrões provinciais em outros aspectos já discutidos (LibBY, 1988, p. 106).

O outro padrão de distribuição da posse de escravos, em que os pequenos plantéis perfaziam a maioria da população escrava e os pequenos proprietários de cativos eram majoritários, predominava no Sul de Minas, na região do Jequitinhonha e Mucuri, nas regiões de Montes Claros e Paracatu e no Oeste Mineiro e Alto Paranaíba. Aliás, na agregação dos resultados em toda a província, esse era o padrão para a distribuição da posse mancípia provincial, apesar das distorções impostas pelas Zonas Metalúrgica-Mantiqueira e Mata (e, de acordo com os resultados do autor, também pelo Triângulo Mineiro): 
Diante de tais resultados, acreditamos que seja válido concluir que na Minas Gerais do segundo quartel do século XIX predominava uma relativa desconcentração na propriedade de escravos. Quanto à base sócio-política do escravismo, podemos afirmar que a desconcentração da propriedade de escravos tenha servido de sustentação ao regime. Tal fato sugere que é importante um estudo sobre essa 'democracia relativa escravista' [...] (p. 107).

Nossos resultados corroboram essa conclusão do autor: realmente, também no Triângulo Mineiro, como de resto na maior parte da província, predominavam os pequenos proprietários de escravos. Assim, acreditamos que a excentricidade dos achados do autor relativos ao Triângulo Mineiro se deva a problemas na amostragem. Um dos problemas é que o autor utilizou, como populações-amostra do Triângulo Mineiro, os arraiais de Desemboque, São José do Tejuco ${ }^{23}$ e São Francisco das Chagas. ${ }^{24} \mathrm{O}$ Desemboque era uma localidade atípica da região, pois surgiu em 1760, por causa da descoberta de ouro na cabeceira do Rio das Velhas por migrantes vindos da região central de Minas. A existência de atividades mineradoras e de fortunas mais antigas diferia da maior parte do Triângulo Mineiro, onde predominavam agricultores e criadores que chegaram à região a partir de 1809. As outras duas localidades, São José e São Francisco, eram esparsamente povoadas no período compreendido pelo autor e devem ter contribuído pouco para os valores agregados na região.

Feita essa ressalva, comparamos os nossos resultados (gráfico 16 e tabela 4) aos do autor, relativos a outras regiões da província (gráficos 17, 18 e 19). Verifica-se que o Triângulo não destoava das outras regiões mineiras que compartilhavam das mesmas estruturas econômico-sociais. Também aqui, os pequenos proprietários de escravos (até 5 escravos) perfaziam a maioria dos proprietários $(61 \%$ do total, contra $66 \%$ no Sul, $72 \%$ no Oeste e $71 \%$ no Alto Paranaíba) e detinham $27 \%$ da população escrava (contra $24 \%$ no Sul, $32 \%$ no Oeste e 37\% no Alto Paranaíba).

É necessário, contudo, lembrarmo-nos de que não estamos diante de uma realidade em que só existissem o pequeno e o médio proprietário de escravos. As figuras mostram que, tanto aqui como em outras regiões mineiras, os senhores de plantéis superiores a 20 escravos, embora somassem apenas 3\% a 7\% dos

23 Hoje Ituiutaba.

24 Hoje Monte Alegre de Minas. 
proprietários, controlavam de 23\% (Oeste) a 35\% (Sul) da população cativa. No Triângulo, os grandes proprietários detinham $25 \%$ do total de escravos. O quadro que talvez mais se aproxime do que até agora vem sendo traçado para o Triângulo (e Minas Gerais) oitocentista seria o de alguns grandes senhores escravistas pontuando a paisagem, e gravitando em torno deles um grande número de pequenos e médios proprietários de escravos.

Para que uma unidade produtiva seja considerada camponesa, é necessário que satisfaça dois critérios: que o trabalho familiar seja a forma predominante de trabalho produtivo, e que os níveis de produção se estabeleçam a partir de um equilíbrio entre o dispêndio de força de trabalho e as demandas do consumo familiar. Nas palavras de Chayanov, "a composição da família é o que determina o volume da atividade econômica. A força de trabalho da unidade familiar é inteiramente determinada pela disponibilidade dos membros da família fisicamente aptos" (1986, p. 53).

Contudo, o uso de trabalho externo à unidade familiar não é incomum nas unidades camponesas. Chayanov (1986) assinalou que o campesinato russo, principalmente nos períodos de semeadura e colheita, lançava mão do assalariamento temporário externo à unidade, como forma de ampliar a força de trabalho familiar. No caso da sociedade colonial e imperial, o escravismo, e não o assalariamento, era a relação de trabalho que dominava a formação social

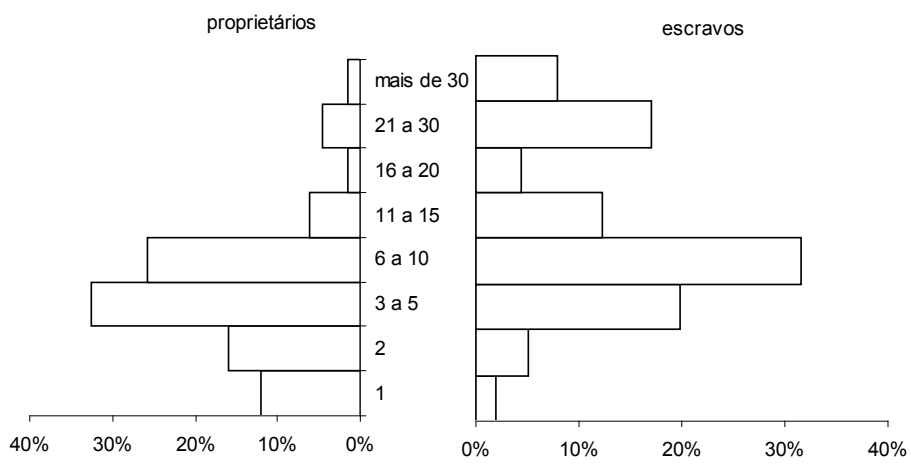

Gráfico 16: distribuição do número de proprietários e da população escrava no Triângulo Mineiro (1822-1861).

Fonte: APU, inventários post mortem (1822-1861). 


\begin{tabular}{l|c|c|c|c|c|c|c|c}
\hline & \multicolumn{7}{|c}{ CLASSIFICAÇÃO DOS PROPRIETÁRIOS SEGUNDO O NÚMERO DE ESCRAVOS } \\
& 1 & 2 & $\begin{array}{c}3 \text { a } \\
5\end{array}$ & $\begin{array}{c}6 \text { a } \\
10\end{array}$ & $\begin{array}{c}11 \text { a } \\
15\end{array}$ & $\begin{array}{c}16 \text { a } \\
20\end{array}$ & $\begin{array}{c}21 \text { a } \\
30\end{array}$ & $\begin{array}{c}\text { mais } \\
\text { de } 30\end{array}$ \\
\hline & $12 \%$ & $16 \%$ & $33 \%$ & $26 \%$ & $6 \%$ & $2 \%$ & $5 \%$ & $2 \%$ \\
\hline EROPRIETÁRIOS & $2 \%$ & $5 \%$ & $20 \%$ & $32 \%$ & $12 \%$ & $4 \%$ & $17 \%$ & $8 \%$ \\
\hline
\end{tabular}

Tabela 4: distribuição do número de proprietários e da população escrava no Triângulo Mineiro (1822-1861).

Fonte: APU, inventários post mortem (1822-1861).

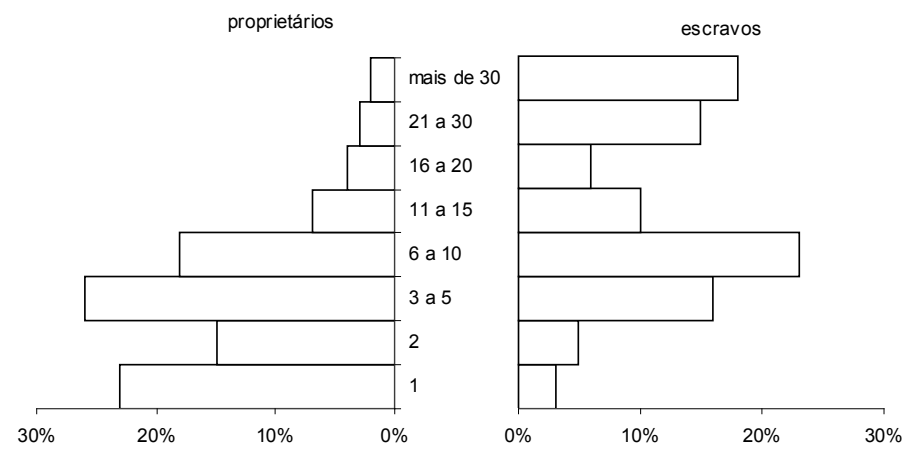

Gráfico 17: distribuição da propriedade de escravos - região Sul (1830-1840)

Fonte: Libby (1988).

e impunha sua lógica às demais. Assim, seria de se esperar que encontrássemos unidades camponesas que eventualmente lançassem mão do trabalho escravo, como forma de complementar ou estender a força de trabalho familiar.

Em nossas fontes, o fogo era a unidade produtiva básica a partir da qual o trabalho se organizava, em pequena ou grande escala. Nos fogos mais modestos, a família, com auxílio ou não de escravos, funcionava como a unidade básica de trabalho, produzindo, ao mesmo tempo, gêneros agrícolas para o autoconsumo e para a comercialização, rebanhos para a venda de garrotes ou para o fabrico 


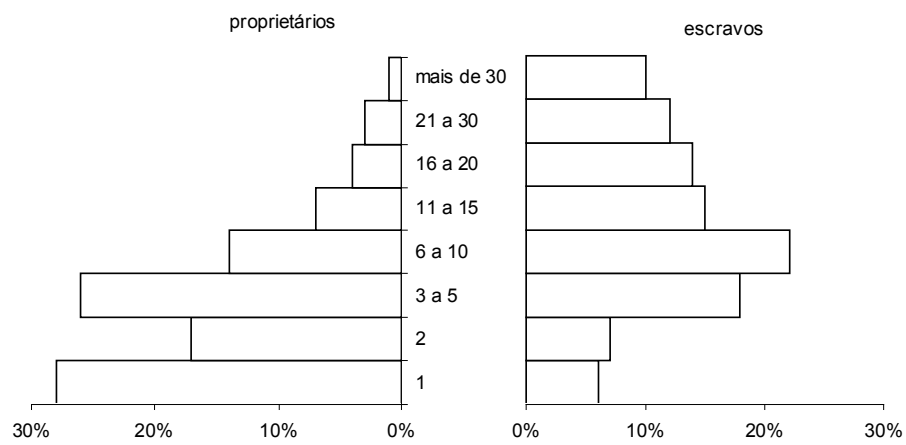

Gráfico 18: distribuição da propriedade de escravos - região Oeste (1830-1840) Fonte: Libby, op. cit., p. 100.

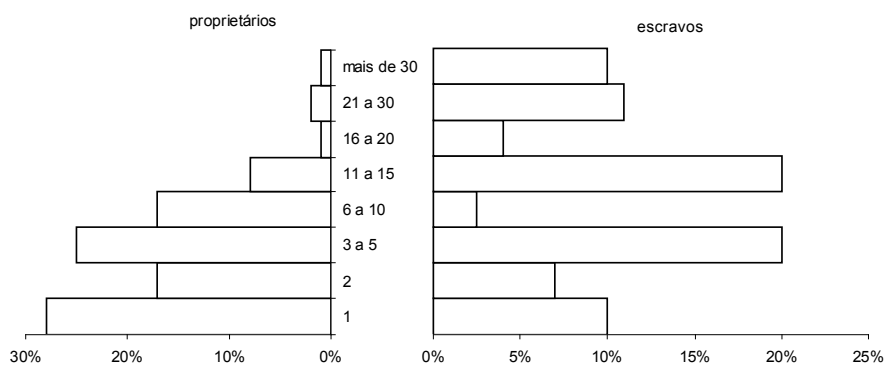

Gráfico 19: distribuição da propriedade de escravos - Alto Paranaíba (1830-1840) Fonte: Libby, op. cit., p. 101.

doméstico de queijos, carneiros para a tosa de lã, tecidos de algodão para uso próprio ou venda. Até mesmo ferramentas como carros, cangas, monjolos e pilões eram produzidos em oficinas domésticas.

No caso dos fogos com até cinco escravos (ou dez, dependendo da constituição etária do plantel), apesar da relação de exploração a que estes estavam 
submetidos, também era impossível distinguir o produto do trabalho escravo do trabalho familiar. Ao trabalho do casal proprietário do fogo e de seus filhos mais velhos se somava o trabalho de um ou dois escravos em idade produtiva. Não havia, nesse caso, uma divisão social do trabalho muito clara, e o recurso ao escravo era uma forma de ampliar o potencial produtivo de uma unidade familiar.

Chayanov demonstrou que o equilíbrio trabalho-consumo da unidade camponesa é dinâmico, isto é, varia em função das transformações demográficas ligadas ao ciclo vital familiar camponês:

Entre famílias de pequeno tamanho, temos um número de famílias jovens, freqüentemente consistindo de recém-casados - o marido e a esposa que apenas recentemente se separaram do lar paterno. Temos um número de famílias consistindo de um número de casais e crianças pequenas, e temos famílias maduras nas quais a segunda geração já trabalha. [...] Finalmente, temos várias famílias idosas que consistem em duas pessoas idosas vivendo sozinhas. [...] Em outras palavras, temos diante de nós todas as fases de desenvolvimento pelas quais a família passa (1986, p. 56).

Assim, nas fases iniciais da história de vida familiar, há uma relação consumidor/produtor igual a 1, que vai aumentando a valores maiores que 1 à medida que o lar camponês vai se enchendo de filhos pequenos. À proporção que estes crescem, a relação consumidor/produtor diminui, até que todos se tornem adultos e plenamente produtivos (gráfico 20).

A partir dessa concepção da dinâmica familiar, Chayanov (1986) procurou compreender o papel desempenhado pelo capital (e pelo processo de acumulação de capital) na unidade camponesa. A grande diferença entre o capital do empreendimento capitalista e o "capital" da unidade camponesa (sementes, equipamentos etc.) é que nesta, diferente daquele, a parte do ganho bruto auferido no processo produtivo, usado na renovação de capital, é indistinguível da parte usada na satisfação do consumo familiar.

É possível, na unidade camponesa, a reprodução ampliada do capital e, portanto, acumulação de capital, mas tal ocorrerá apenas se for visto como vantajoso pela família, isto é, se o esforço adicional de trabalho para obter excedentes para o investimento levar, com este, a um nível de satisfação maior das demandas familiares. Se aumentar a relação consumidor/produtor, deve-se 
aumentar proporcionalmente a penosidade do trabalho dos produtores para aumentar a produção e, em tal situação, o investimento em capital pode se tornar vantajoso. Assim, o investimento e a acumulação não são vistos como um fim em si mesmo, mas como parte de uma estratégia de se buscar um equilíbrio trabalho/consumo em melhores condições.

A partir dos títulos de herdeiros constantes nos inventários post mortem, foi possível reconstituir algumas das características demográficas das famílias triangulinas oitocentistas. Neles, eram informados os nomes dos filhos, suas idades, estado civil e local de moradia. Assim, pudemos construir fichas de família para a maioria dos inventários pesquisados, como já mostramos no capítulo 2. Pudemos, assim, comparar o número de membros e a idade da família com variáveis econômicas, como número de escravos, terras e gado.

Excluímos de nossa amostra os inventários de proprietários de mais de 10 escravos, de casais sem filhos e de comerciantes, mantendo os que

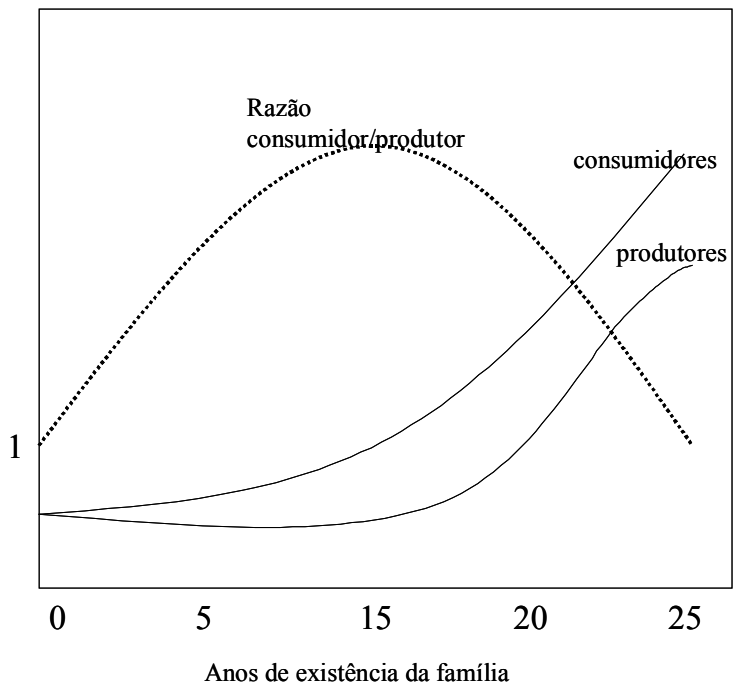

Gráfico 20: curva de Chayanov para a razão consumidor/produtor em função da idade da família. Fonte: Chayanov (1986). 
não possuíam escravos. Dividimos as famílias em famílias jovens (filho mais velho menor que 11 anos), maduras (filho mais velho menor que 20 anos) e idosas (filho mais velho maior que 30 anos ou maioria dos filhos casada), e correlacionamos esses grupos com seus respectivos plantéis médios de escravos e patrimônios fundiários. Obtivemos os gráficos 21 e 22 .

Pode-se notar que, na realidade vivida pelas famílias triangulinas, escravos e terra ocupavam o lugar do "capital" dos camponeses russos estudados por Chayanov. Em outras palavras, diante do padrão de baixo nível de desenvolvimento das forças produtivas, vigente na região, investir na aquisição de terras e cativos era a única forma de ampliar a produtividade da força de trabalho e alcançar o equilíbrio na satisfação do consumo familiar.

Porém, para avançar em nossas considerações, é necessário não só comparar a idade da família com o número de escravos, mas a força de trabalho familiar com a força de trabalho escrava, em função da idade. Usamos a tabela de Chayanov (tabela 5) para calcular a força produtiva individual de cada membro da família em função da idade e sexo, e fizemos o mesmo com os escravos. Nessa tabela, o autor considerou que a idade produtiva começaria aos 13 anos, e que um homem adulto jovem teria índice de produtividade e consumo igual a 1 , enquanto as mulheres teriam um índice de 0,8 .

A aplicação dos parâmetros de Chayanov, construídos para famílias camponesas russas do início do século XX, é passível de crítica, por se tratar o nosso objeto de estudo de uma realidade cultural e histórica diferente. Mas, por não dispormos de outras referências, usaremos os coeficientes desse autor, com essa ressalva.

Calculamos a força produtiva média, familiar e escrava, com base nos coeficientes da tabela de Chayanov, para cada faixa de idade das famílias, baseados na idade e sexo dos membros e dos cativos, conforme se vê no gráfico 23. Percebe-se que, até a família atingir de 10 a 15 anos de existência, a força de trabalho familiar superava a escrava, na média dos fogos. Dos 15 aos 20 anos, quando a família tinha sua mais alta relação consumidor/trabalhador (grande número de filhos menores), a força de trabalho escrava chegava ao seu máximo, para decair logo depois, dos 20 aos 30 anos, quando o número de dependentes diminuía, e parte dos escravos era possivelmente vendida ou dada em dote às filhas.

Com isso, podemos falar de unidades camponesas com escravos, pois a presença dos pequenos plantéis de cativos não descaracterizava o trabalho 


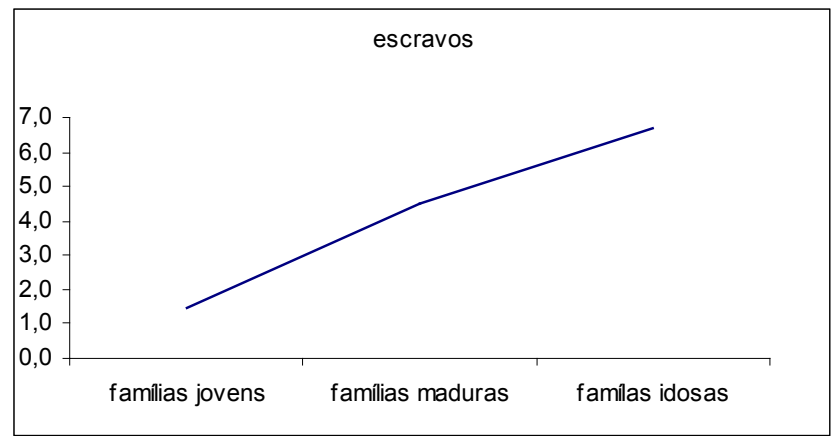

Gráfico 21: plantéis médios de escravos em função da idade da família, para famílias com menos de 10 escravos, no termo de Uberaba (1822-1861).

Fonte: APU, inventários post mortem (1822-1861).

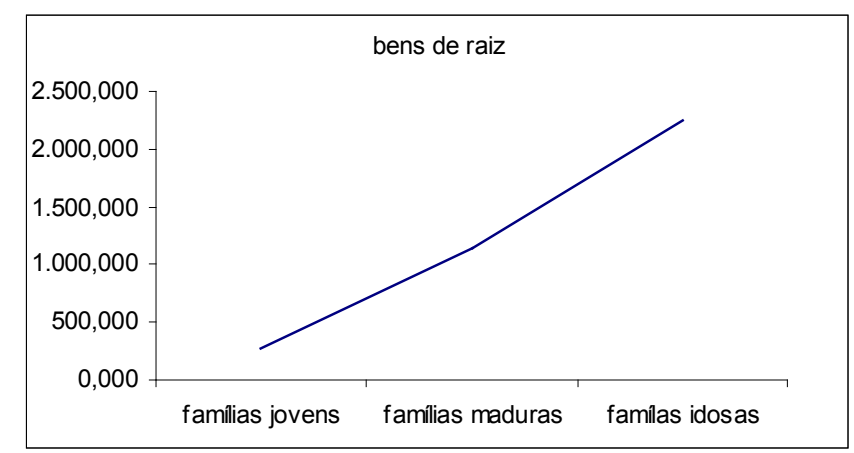

Gráfico 22: patrimônio fundiário em função da idade da família, para famílias com menos de 10 escravos, no termo de Uberaba (1822-1861).

Fonte: APU, inventários post mortem (1822-1861).

familiar, antes o ampliava. Tomamos o cuidado de não chamar tais unidades de escravistas, pois isso pressuporia uma divisão social do trabalho entre produtores diretos escravos e não-produtores livres nas unidades camponesas, o que vimos ser improvável, e o que de resto as descaracterizaria como camponesas.

É muito provável que as fazendas e sítios triangulinos fossem semelhantes, na forma de organização do trabalho, às fazendas descritas por 


\begin{tabular}{|c|c|c|c|c|c|c|c|c|c|c|c|c|c|c|}
\hline \multirow{2}{*}{\multicolumn{2}{|c|}{$\begin{array}{c}\text { Years of } \\
\text { Family's } \\
\text { Existence }\end{array}$}} & \multirow{2}{*}{$\begin{array}{c}\text { Married } \\
\text { Couple }\end{array}$} & \multicolumn{9}{|c|}{ Children } & \multicolumn{2}{|c|}{$\begin{array}{l}\text { Total in } \\
\text { Family }\end{array}$} & \multirow{2}{*}{$\begin{array}{c}\text { Consumers } \\
\div \text { Workers } \\
\end{array}$} \\
\hline & & & 1 & 2 & 3 & 4 & 5 & 6 & 7 & 8 & 9 & Consumers & Workers & \\
\hline 1 & $\ldots$ & 1.8 & - & - & - & - & - & - & - & - & - & 1.8 & 1.8 & 1.00 \\
\hline 2 & $\ldots$ & 1.8 & 0.1 & - & - & - & - & - & - & - & - & 1.9 & 1.8 & 1.06 \\
\hline 3 & $\ldots$ & 1.8 & 0.3 & - & - & - & - & - & - & - & - & 2.1 & 1.8 & 1.17 \\
\hline 4 & $\ldots$ & 1.8 & 0.3 & - & - & - & - & - & - & - & - & 2.1 & 1.8 & 1.17 \\
\hline 5 & $\because$ & 1.8 & 0.30 & 0.1 & - & - & - & - & - & - & - & 2.2 & 1.8 & 1.22 \\
\hline 6 & $\cdots$ & 1.8 & 0.30 & 0.3 & - & - & - & - & - & - & - & 2.4 & 1.8 & 1.33 \\
\hline 7 & $\ldots$ & 1.8 & 0.30 & 0.3 & - & - & - & - & - & - & - & 2.4 & 1.8 & 1.39 \\
\hline 8 & $\ldots$ & 1.8 & 0.3 & 0.3 & 0.1 & - & - & - & - & - & - & 2.5 & 1.8 & 1.39 \\
\hline 9 & $\ldots$ & 1.8 & 0.51 & 0.3 & 0.3 & - & - & - & - & - & - & 2.9 & 1.8 & 1.61 \\
\hline 10 & $\ldots$ & 1.8 & 0.5 & 0.3 & 0.3 & - & - & - & - & - & - & 2.9 & 1.8 & 1.61 \\
\hline 11 & $\ldots$ & 1.8 & 0.5 & 0.3 & 0.3 & 0.1 & - & - & - & - & - & 3.0 & 1.8 & 1.66 \\
\hline 12 & $\ldots$ & 1.8 & 0.5 & 0.5 & 0.3 & 0.3 & - & - & - & - & - & 8.4 & 1.8 & 1.88 \\
\hline 13 & $\ldots$ & 1.8 & 0.50 & 0.5 & 0.3 & 0.3 & - & - & - & - & - & 3.1 & 1.8 & 1.88 \\
\hline 14 & $\ldots$ & 1.8 & 0.5 & 0.5 & 0.3 & 0.3 & 0.1 & - & - & - & - & 3.5 & 1.8 & 1.94 \\
\hline 15 & $\ldots$ & 1.8 & 0.7 & 0.5 & 0.5 & 0.8 & 0.3 & - & - & - & - & 4.1 & 2.5 & 1.64 \\
\hline 16 & $\ldots$ & 1.8 & 0.7 & 0.5 & 0.5 & 0.3 & 0.3 & - & - & - & - & 4.1 & 2.5 & 1.64 \\
\hline 17 & $\ldots$ & 1.8 & 0.7 & 0.5 & 0.5 & 0.3 & 0.3 & 0.1 & - & - & - & 4.2 & 2.5 & 1.68 \\
\hline 18 & $\ldots$ & 1.8 & 0.7 & 0.7 & 0.5 & 0.5 & 0.8 & 0.8 & - & - & - & 1.8 & 3.2 & 1.50 \\
\hline 19 & $\ldots$ & 1.8 & 0.7 & 0.7 & 0.5 & 0.5 & 0.8 & 0.3 & - & - & - & 1.8 & 3.2 & 1.50 \\
\hline 20 & $\cdots$ & 1.8 & 0.9 & 0.7 & 0.5 & 0.5 & 0.3 & 0.8 & 0.1 & - & - & 5.1 & 3.4 & 1.50 \\
\hline 21 & $\ldots$ & 1.8 & 0.9 & 0.7 & 0.7 & 0.5 & 0.5 & 0.8 & 0.3 & - & - & 5.7 & 4.1 & 1.39 \\
\hline 22 & $\ldots$ & 1.8 & 0.9 & 0.7 & 0.7 & 0.5 & 0.5 & 0.8 & 0.8 & - & - & 5.7 & 4.1 & 1.39 \\
\hline 23 & $\ldots$ & 1.8 & 0.9 & 0.9 & 0.7 & 0.5 & 0.5 & 0.3 & 0.8 & 0.1 & - & 6.0 & 4.3 & 1.39 \\
\hline 24 & $\ldots$ & 1.8 & 0.9 & 0.9 & 0.7 & 0.7 & 0.5 & 0.5 & 0.3 & 0.8 & - & 6.6 & 5.0 & 1.32 \\
\hline 25 & $\ldots$ & 1.8 & 0.9 & 0.9 & 0.7 & 0.7 & 0.5 & 0.5 & 0.3 & 0.3 & - & 6.6 & 5.0 & 1.32 \\
\hline 26 & $\ldots$ & 1.8 & 0.9 & 0.9 & 0.9 & 0.7 & 0.5 & 0.5 & 0.3 & 0.3 & 0.1 & 6.9 & 5.2 & 1.32 \\
\hline
\end{tabular}

Tabela 5: peso de produtores e consumidores em função da idade da família (força produtiva individual em negrito).

Fonte: Chayanov (1986, p. 58).

Saint Hilaire no Alto Rio Grande, na comarca do Rio das Mortes. Essa região, que correspondia ao sul da província de Minas Gerais, tinha uma distribuição da posse de cativos semelhante à do Triângulo, conforme vimos na comparação entre os gráficos 16 e 17. Segundo o botânico francês, a presença de escravos não significava ausência do trabalho familiar, pois os fazendeiros

trabalham lado a lado com os escravos, passando a maior parte do tempo nas plantações e em contato com os animais. [...] Os filhos dos fazendeiros se dedicam todos ao trabalho. Um conduz as tropas de burros, outro cuida dos animais e um terceiro das plantações (1975 b, p. 55).

Daí a presença de uma posse pulverizada de escravos, isto é, grande número de proprietários de pequenos plantéis cativos: "os agricultores da região do Rio Grande [...] não têm sob sua responsabilidade um número excessivo de escravos" (p. 55). Como se vê, o trabalho escravo funcionava como uma extensão do trabalho familiar. 


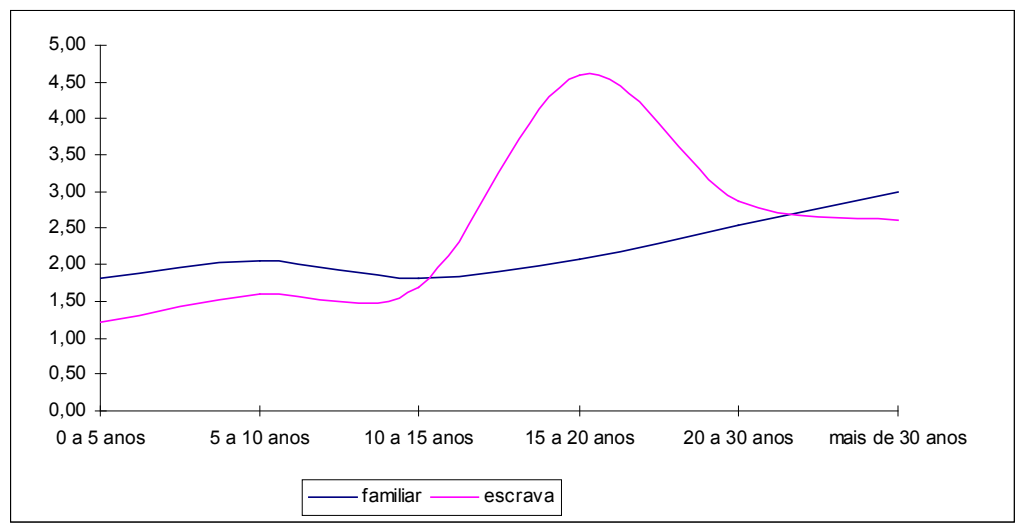

Gráfico 23: força de trabalho familiar e escrava, por grupo etário de famílias, no termo de Uberaba (1822-1861).

Fonte: APU, inventários post mortem (1822-1861).

Pela tabela 6, pode-se ver que os fogos sem escravos variaram de $16 \%$ a $24 \%$, ao longo do período em questão. Tais unidades usavam inequivocamente o trabalho familiar. Nos exemplos que se seguem, procuraremos comparálas às unidades que dispunham de alguns escravos, buscando diferenças e semelhanças qualitativas.

O velho Francisco Antônio Ribeiro dos Santos ${ }^{25}$ já morava sozinho com sua esposa Violante, quando ela morreu em 1827. Seus dois filhos mais novos, Manuel e José, já estavam casados e moravam longe dos pais, um em Tamanduá ${ }^{26}$ e outro em Santana do Rio das Velhas. Os mais velhos já haviam morrido, deixando dezoito netos. Não tinha escravos, e em seu sítio, com uma casa coberta de capim, paiol e monjolo, cuidava sozinho de suas 48 cabeças de gado, além de dispor de um machado, uma foice e uma enxada para suas lavouras.

Seu cotidiano era muito parecido com o de João Caetano Barbosa, ${ }^{27}$ que também vivia numa casa coberta de capim, com paiol, rego d'água e monjolo. Só que este, mais jovem, contava com a ajuda de sua mulher Justa

25 APU, Inventário de Violante Maria de Jesus (07/04/1827), maço N27 caixa 459.

26 Hoje Itapecerica.

27 APU, inventário de Justa Inocência da Conceição (24/04/1832), maço N11, caixa 470. 


\begin{tabular}{l|c|c|c}
\hline PARTICIPAÇÃO DE CADA GRUPO DE PROPRIETÁRIOS SOBRE O TOTAL \\
\hline & $1822-41$ & $1842-51$ & $1852-61$ \\
\hline SEM ESCRAVOS & $16 \%$ & $22 \%$ & $24 \%$ \\
1 A 5 ESCRAVOS & $55 \%$ & $40 \%$ & $49 \%$ \\
6 A 10 ESCRAVOS & $16 \%$ & $25 \%$ & $22 \%$ \\
11 A 20 ESCRAVOS & $6 \%$ & $9 \%$ & $2 \%$ \\
MAIS DE 20 ESCRAVOS. & $7 \%$ & $4 \%$ & $2 \%$ \\
\hline
\end{tabular}

Tabela 6: distribuição da posse de escravos de 1822 a 1861, no termo de Uberaba. Fonte: APU, inventários post mortem (1822-1861).

e das filhas Maria e Luísa, já moças, e com o trabalho dos escravos José Crioulo, José da Nação e Benedita, mãe da pequena Eva, de 10 anos. Esses três homens dispunham de duas foices, três machados, duas enxadas e um carro, puxado por duas parelhas de bois carreiros, para seu trabalho diário. João não possuía gado de corte ou de leite, mas tinha uma engenhoca e um alambique onde fabricava cachaça, que provavelmente vendia no arraial de Dores do Campo Formoso.

Como essas duas famílias, dezenas de outras dependiam do trabalho próprio para sobreviver, no Triângulo Mineiro nos primórdios de sua ocupação, e eram elas, predominantemente, que compunham a paisagem rural de então. A diferença entre o sítio de João e o sítio de Antônio é que, naquele, seu proprietário, sem escravos e sem filhos próximos, tinha que despender um esforço muito maior para sobreviver no dia-a-dia. Já Antônio, contando com a sua própria força de trabalho e mais a de dois moços escravos, obtinha o necessário para seu sustento com muito menos penosidade. Mas o que ambos buscavam, no entanto, era o que, só um século mais tarde, um economista russo conseguiria formular de uma maneira surpreendentemente simples: reproduzir suas existências e de suas famílias da melhor forma, e com o menor esforço possível. 


\section{A sociedade escravista do Triângulo Mineiro}

O Triângulo Mineiro teve sua ocupação pioneira iniciada nos primeiros anos do século XIX, por migrantes vindos da região central da capitania depois província — de Minas Gerais. Nesse período, surgiu uma sociedade que, ao mesmo tempo em que era semelhante à sociedade inclusa, colonial ou imperial, contava com algumas peculiaridades.

Como de resto no Brasil de então, a sociedade triangulina, desde muito cedo, exibiu os traços de uma ordem social fundamentada no tradicionalismo, na valorização da fidalguia e no desprezo pelos "defeitos mecânicos", e na escravidão como um valor profundamente arraigado em todas as consciências. Valores típicos das sociedades de ordens do Antigo Regime, eram eles que informavam aqueles homens e mulheres que criaram as primeiras fazendas e sítios nas matas e cerrados do Extremo Oeste Mineiro.

Nessa economia pioneira, a produção dependia principalmente de uma utilização extensiva e predatória dos solos, madeiras e pastagens naturais. O nível de desenvolvimento das forças produtivas era muito baixo e, por isso, mesmo os maiores potentados rurais acumulavam sua riqueza sob formas não-capitalistas, como escravos e terras. Além de conferir prestígio e distinção social numa sociedade de ordens, possuir homens e fazendas era a única forma de expandir a escala da produção num universo técnico tão limitado.

Apesar da forte diferenciação social, a divisão social do trabalho era pouco pronunciada, inclusive entre pequenas e grandes unidades produtivas, voltandose todas elas para a mesma gama de atividades, diferenciando-se uma da outra apenas na escala da produção.

O financiamento das atividades produtivas era feito pelos detentores das maiores fortunas fundiárias e escravistas, que mantinham os demais produtores numa rede de endividamento pelo capital usurário. Os grandes fazendeiros, por sua vez, contraíam dívidas com os capitalistas mercantis do Rio de Janeiro e com instituições como a Santa Casa de Misericórdia.

O mercado local era fortemente limitado pela hegemonia de relações de trabalho não capitalistas, pela produção de autoconsumo e pela pouca especialização entre os produtores, o que se refletia, por exemplo, na baixa liquidez. Esses traços (concentração de riquezas, capital usurário, mercados imperfeitos, pequena divisão social do trabalho) não eram característicos apenas 
da sociedade do Triângulo oitocentista, mas de outras regiões como o Rio de Janeiro e a área aurífero-metalúrgica de Minas, e de sociedades européias do Antigo Regime.

A despeito do grande número de pequenos proprietários, a propriedade fundiária não era essencial para garantir estabilidade no acesso à terra. A possibilidade de negociar e herdar sítios desvinculados da terra mostrava a estabilidade de um grande número de posseiros que viviam em fazendas alheias, com a permissão de seus proprietários.

Nessa sociedade, possuir escravos não era privilégio apenas dos grandes senhores. Havia uma pulverização da posse mancípia, e por isso o mais comum era encontrar proprietários de um a cinco escravos. Esses escravos, porém, não substituíam nem descaracterizavam o trabalho familiar, mas o estendiam, não havendo nessas pequenas unidades uma divisão do trabalho muito clara entre escravos e seus senhores. Tais unidades, por terem sido fundamentadas no trabalho familiar, funcionavam segundo a dinâmica do equilíbrio trabalho/ consumo, diferente da lógica de mercado do sistema capitalista.

Até agora, não abordamos ainda um curioso segmento da população do Triângulo Mineiro oitocentista: os moradores exclusivos dos arraiais, aqueles que, nos inventários, aparecem como tendo a posse de glebas urbanas, mas não eram proprietários fundiários rurais. Esse grupo, um dos mais pobres da sociedade de então, será o assunto do próximo capítulo. 